\title{
Identification of a Novel Series of Potent Organosilicon Mosquito Repellents
}

Akshay S. Kulkarni, ${ }^{a, b}$ Remya Ramesh, ${ }^{\text {a,b }}$ Safal Walia, ${ }^{d}$ Shahebaz I. Sayyad,c Ganesh B. Gathalkar, Seetharamsing Balamkundu, ${ }^{\mathrm{a}, \mathrm{b}}$ Manali Joshi, ${ }^{\mathrm{d}}$ Avalokiteswar Sen, ${ }^{* \mathrm{~b}, \mathrm{c}}$ D. Srinivasa Reddy*a,b,e

a) CSIR-National Chemical Laboratory, Division of Organic Chemistry, Dr. Homi Bhabha Road, Pune, 411008, India

b) Academy of Scientific and Innovative Research (AcSIR), Ghaziabad, 201002, India

c) CSIR-National Chemical Laboratory, Laboratory of Entomology, Dr. Homi Bhabha Road, Pune, 411008, India

d) Bioinformatics Centre, S. P. Pune University, Pune, 411007, India

e) Current address: CSIR-Indian Institute of Integrative Medicine, Jammu, 180001, India

*Corresponding authors: Dr. Avalokiteswar Sen (a.sen@ncl.res.in); Dr. D. Srinivasa Reddy (reddy.ds@iiim.res.in)

\section{Table of contents:}

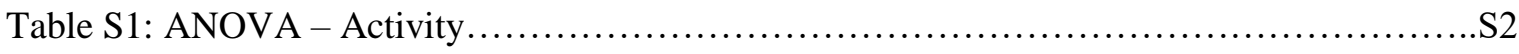

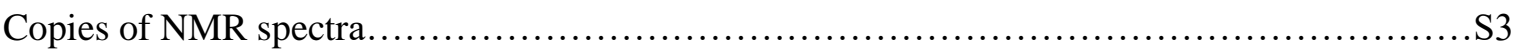


Table S1: ANOVA - Activity

\begin{tabular}{lrrrrr}
\hline \multicolumn{1}{c}{ Cases } & Sum of Squares & \multicolumn{1}{c}{ df } & Mean Square & \multicolumn{1}{c}{ F } & p \\
\hline Compound & $6.806 e+6$ & 27.000 & 252058.168 & $2650.305<.001$ \\
Concentration & 626346.604 & 1.000 & 626346.604 & $6585.818<.001$ \\
Compound $*$ Concentration & 263470.696 & 27.000 & 9758.174 & $102.604<.001$ \\
Residual & 21303.600 & 224.000 & 95.105 & & \\
\hline
\end{tabular}

Note. Type III Sum of Squares 


\section{Copies of NMR spectra}




\section{Figure S1: ${ }^{1} \mathrm{H}$ NMR of 2 in $\mathrm{CDCl}_{3}(400 \mathrm{MHz})$}
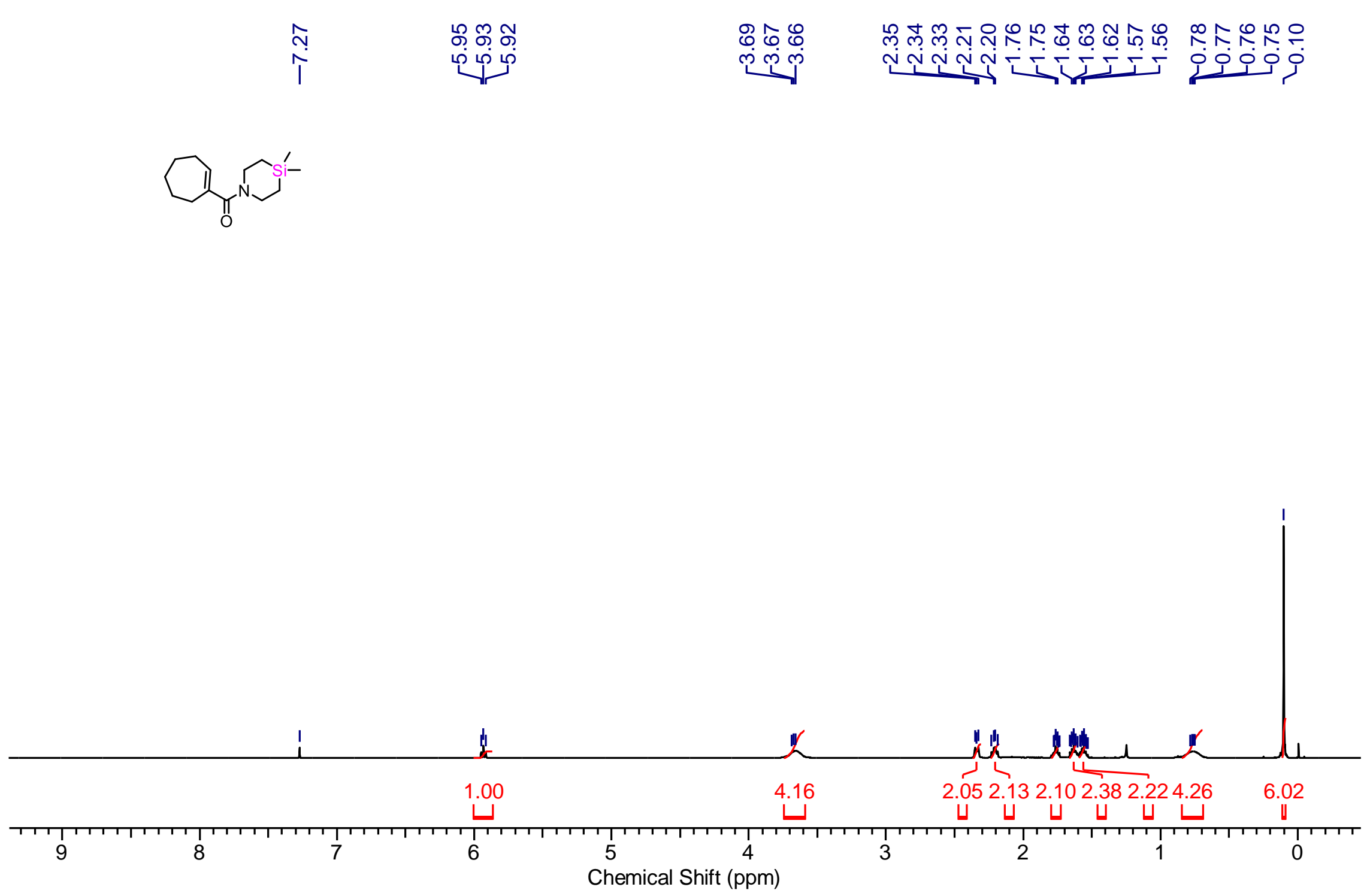


\section{Figure S2: ${ }^{13} \mathrm{C}$ NMR of 2 in $\mathrm{CDCl}_{3}(100 \mathrm{MHz})$}

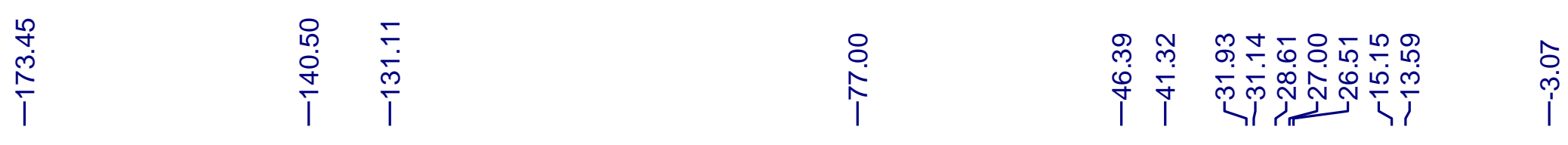
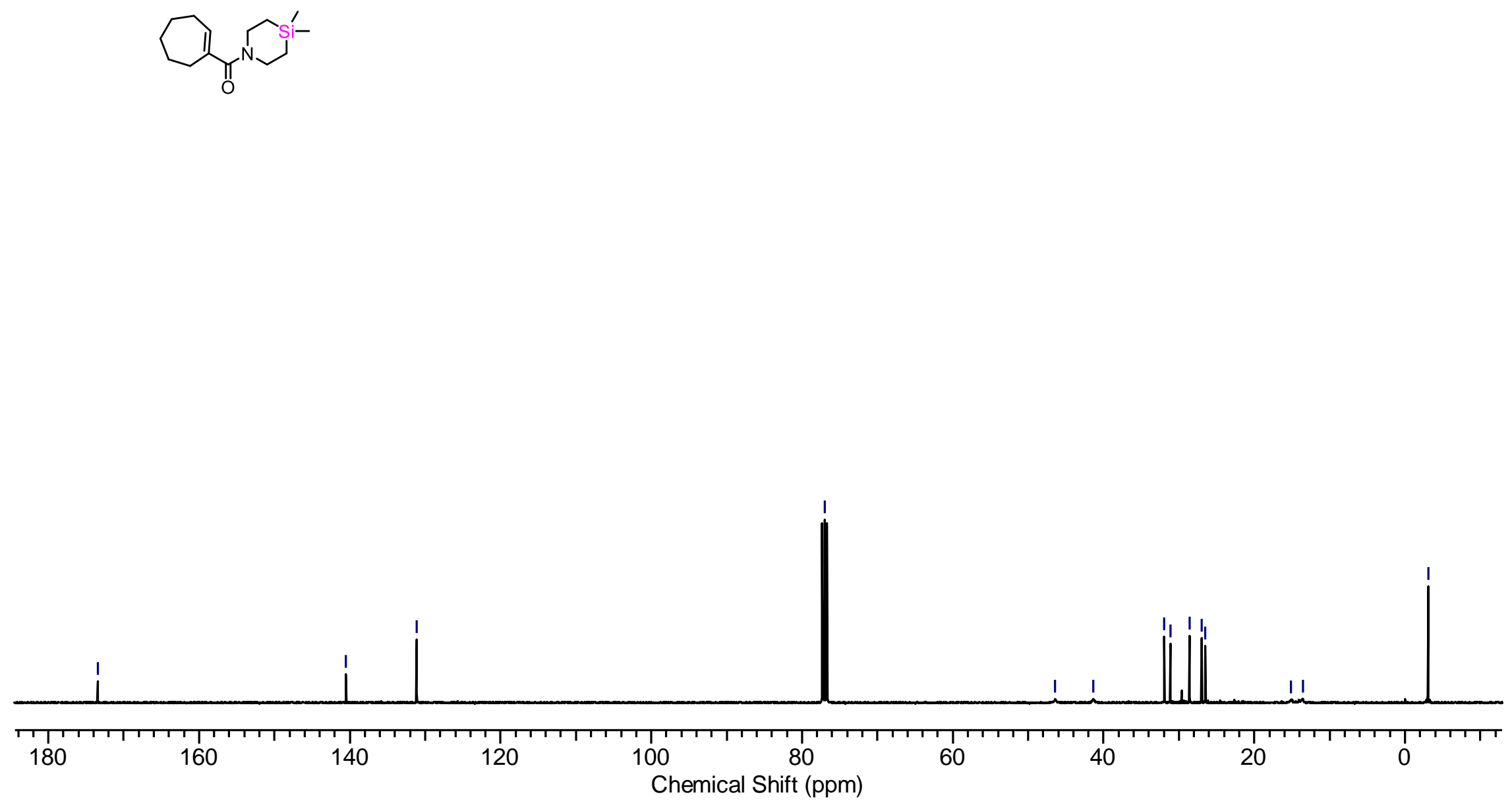


\section{Figure S3: ${ }^{1} \mathrm{H}$ NMR of 3 in $\mathrm{CDCl}_{3}(200 \mathrm{MHz})$}
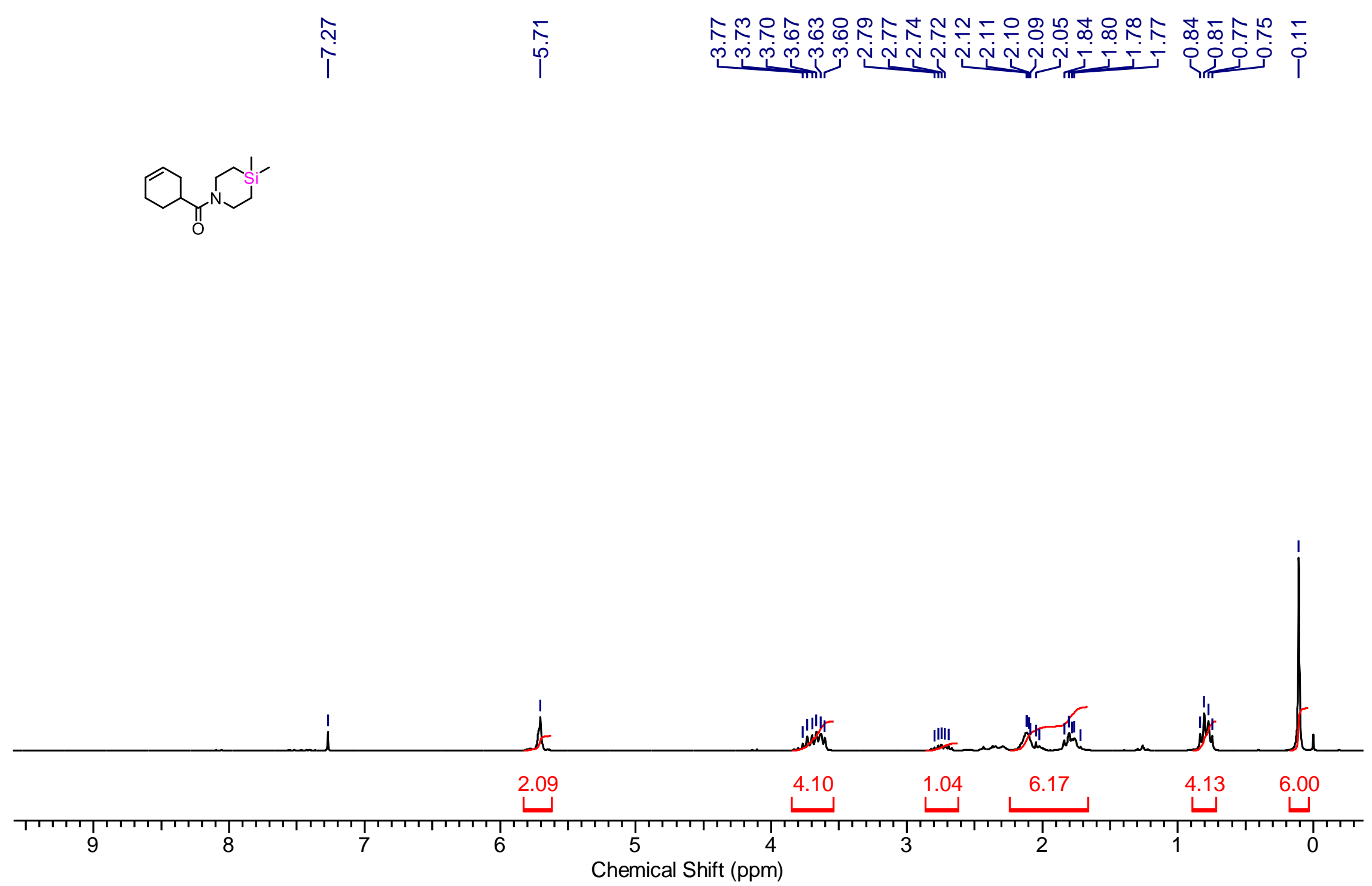


\section{Figure S4: ${ }^{13} \mathrm{C}$ NMR of 3 in $\mathrm{CDCl}_{3}(50 \mathrm{MHz})$}

\begin{tabular}{|c|c|c|c|c|}
\hline 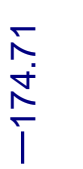 & 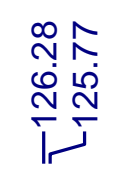 & 吕 & 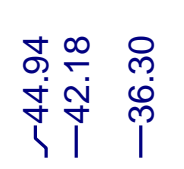 & 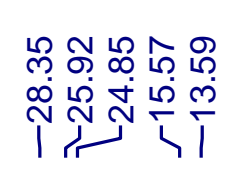 \\
\hline
\end{tabular}
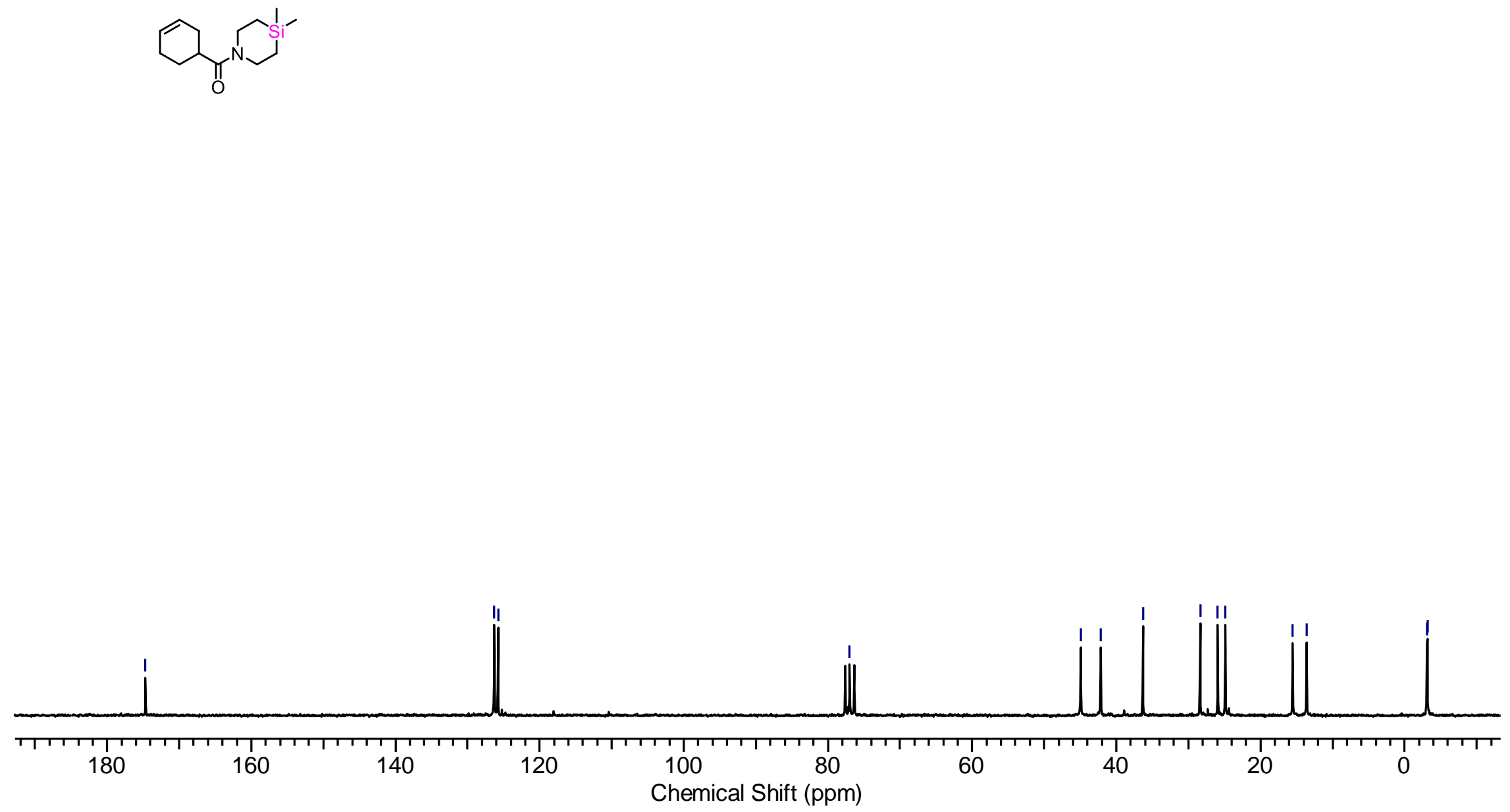


\section{Figure S5: ${ }^{1} \mathrm{H}$ NMR of 4 in $\mathrm{CDCl}_{3}(400 \mathrm{MHz})$}
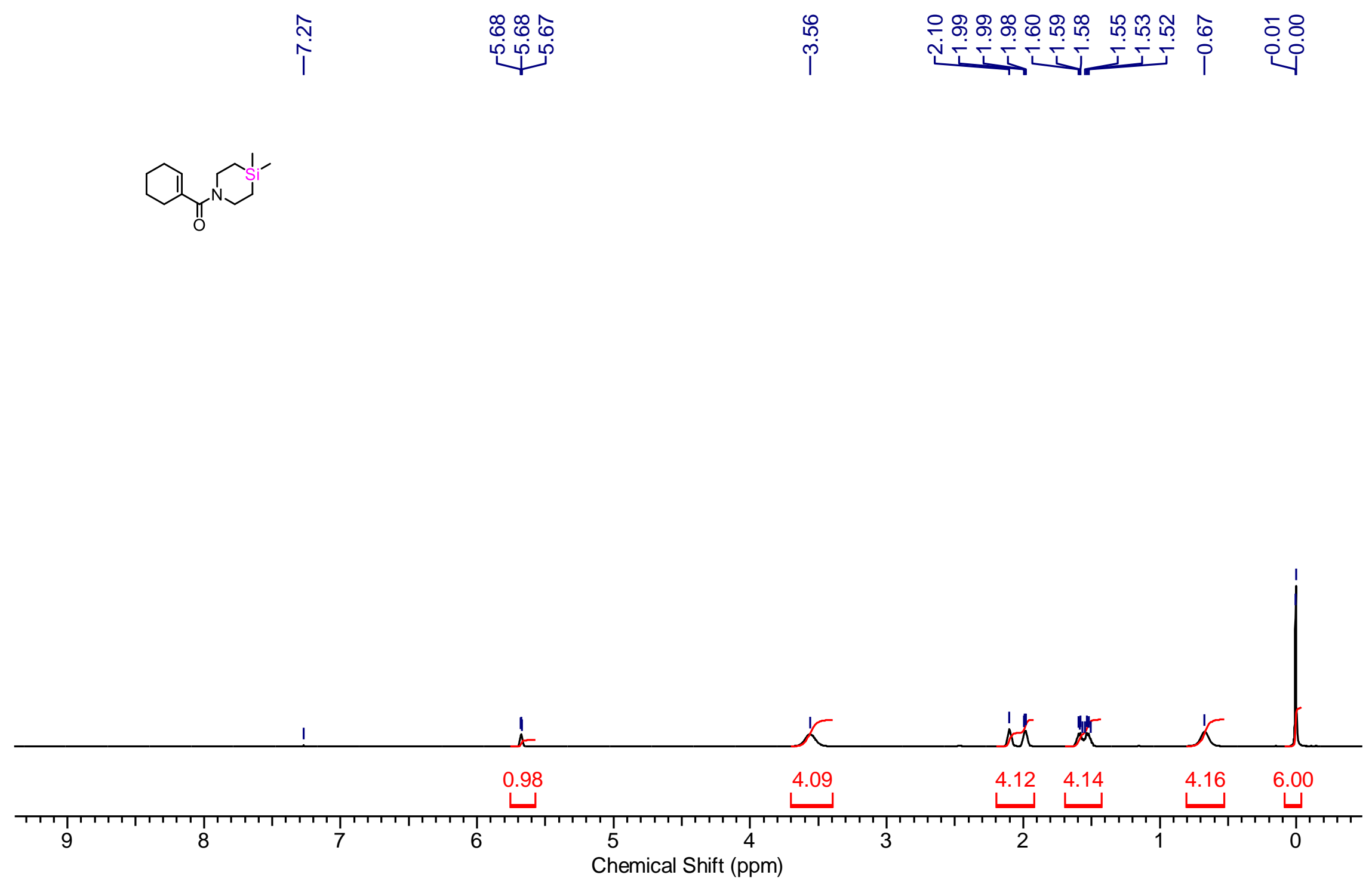


\section{Figure S6: ${ }^{13} \mathrm{C}$ NMR of 4 in $\mathrm{CDCl}_{3}(100 \mathrm{MHz})$}
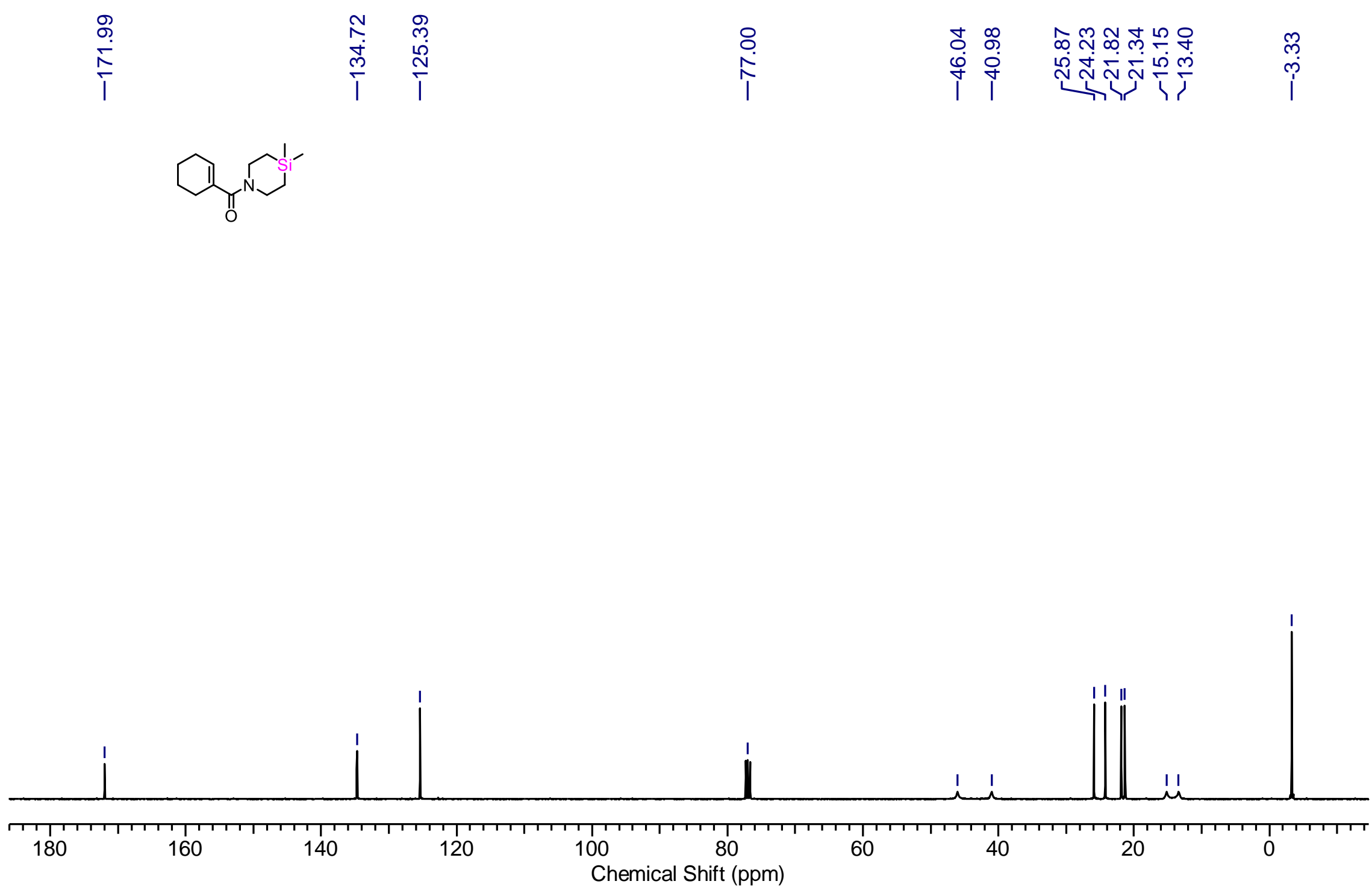


\section{Figure S7: ${ }^{1} \mathrm{H}$ NMR of 5 in $\mathrm{CDCl}_{3}(400 \mathrm{MHz})$}
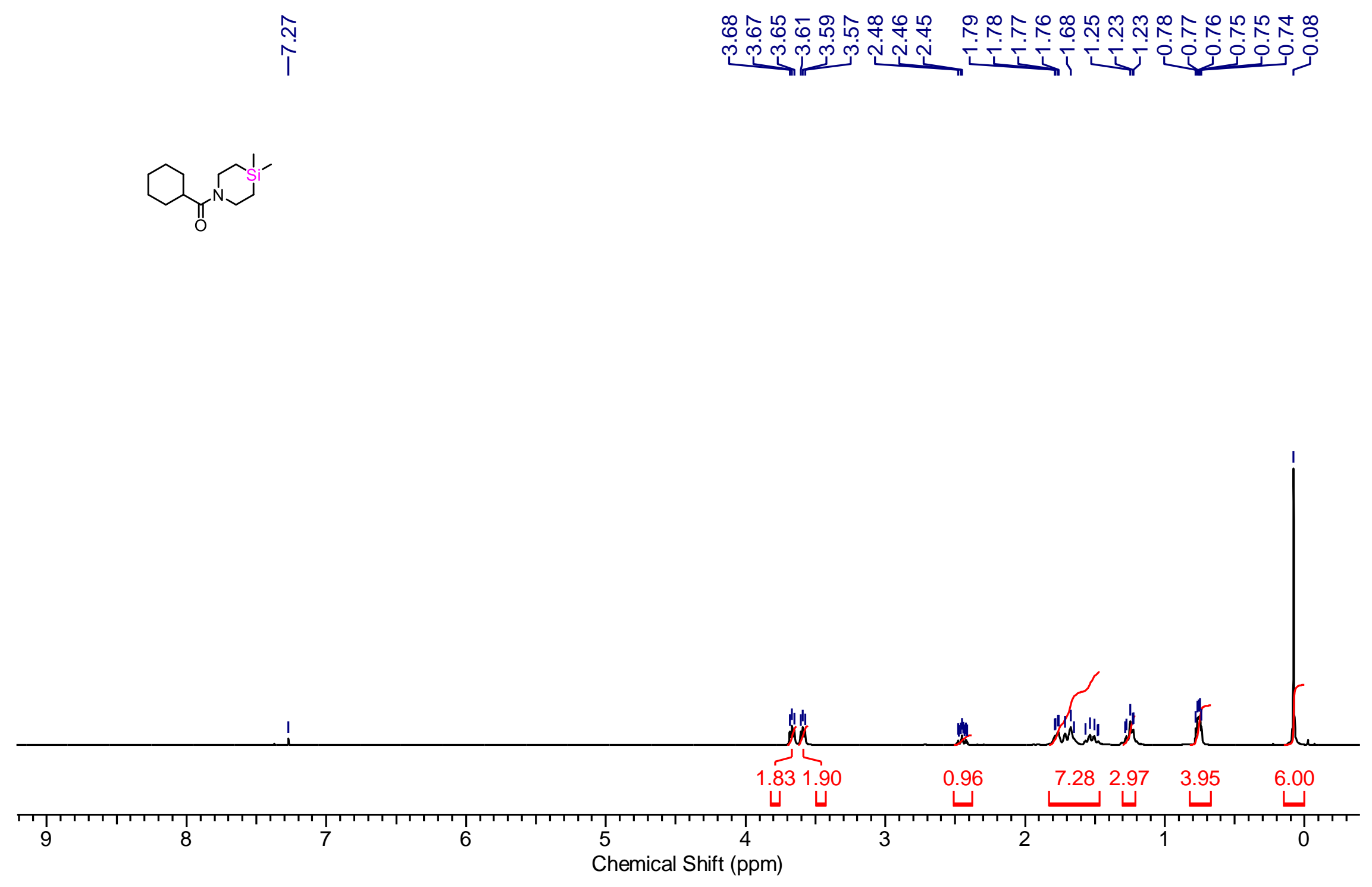


\section{Figure S8: ${ }^{13} \mathrm{C} \mathrm{NMR}$ of 5 in $\mathrm{CDCl}_{3}(100 \mathrm{MHz})$}
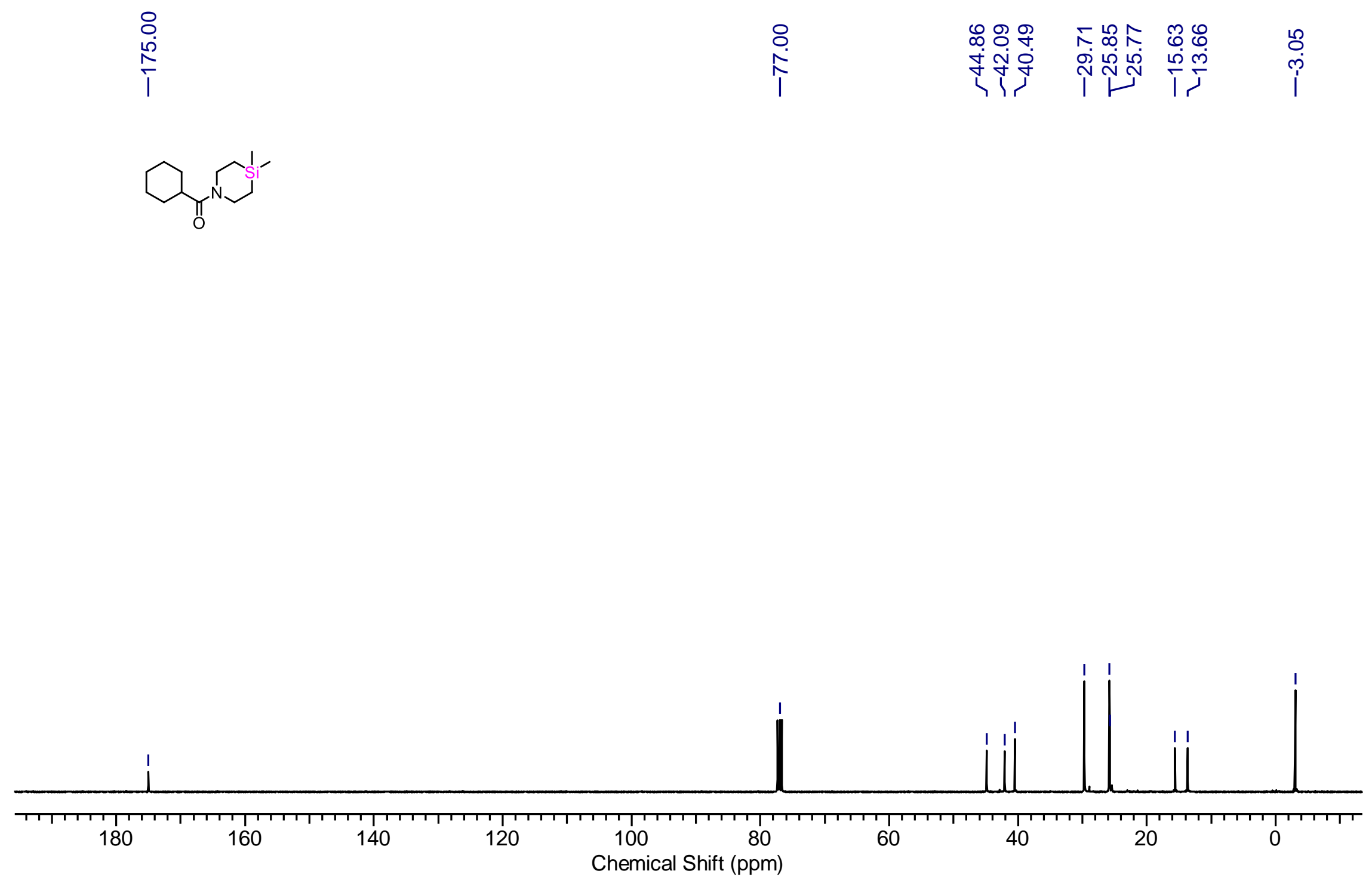


\section{Figure S9: ${ }^{1} \mathrm{H}$ NMR of 6 in $\mathrm{CDCl}_{3}(400 \mathrm{MHz})$}

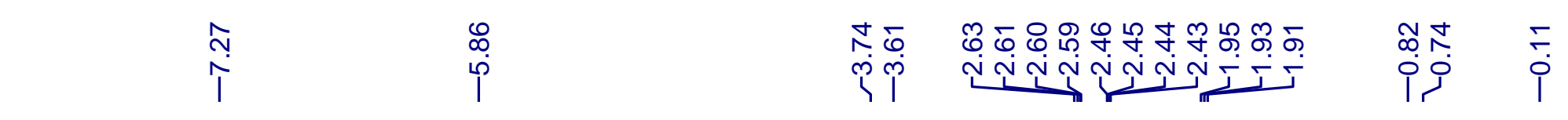
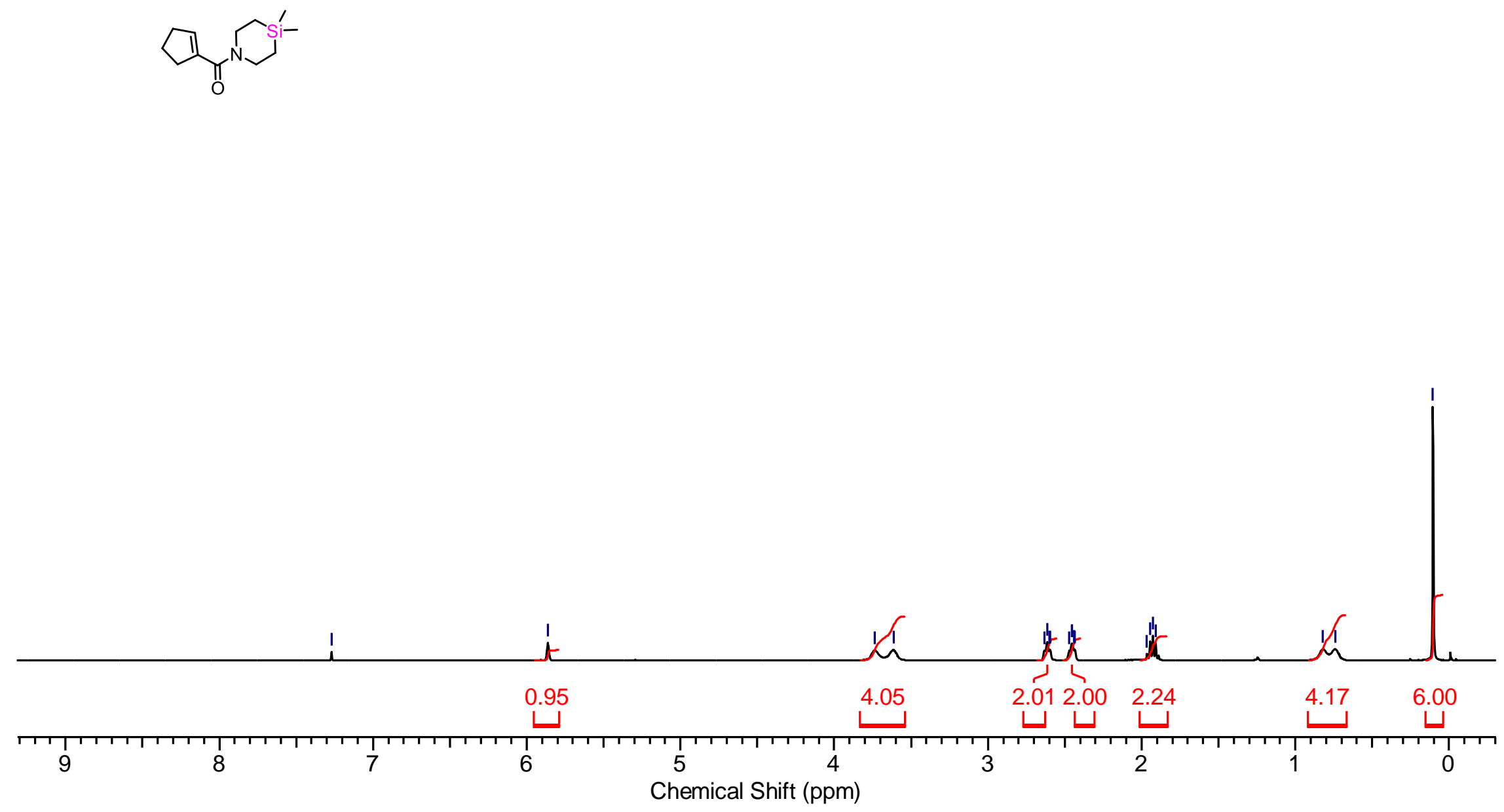


\section{Figure S10: ${ }^{13} \mathrm{C}$ NMR of 6 in $\mathrm{CDCl}_{3}(100 \mathrm{MHz})$}

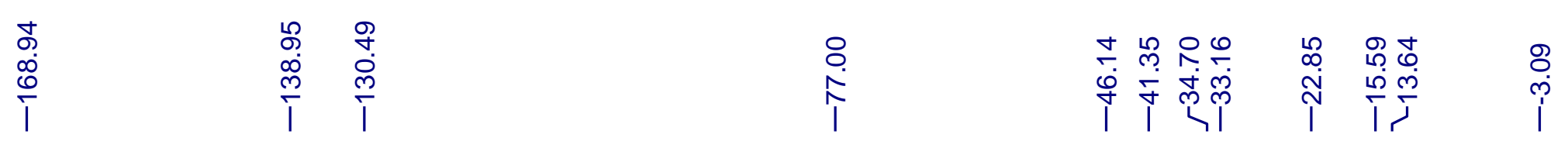
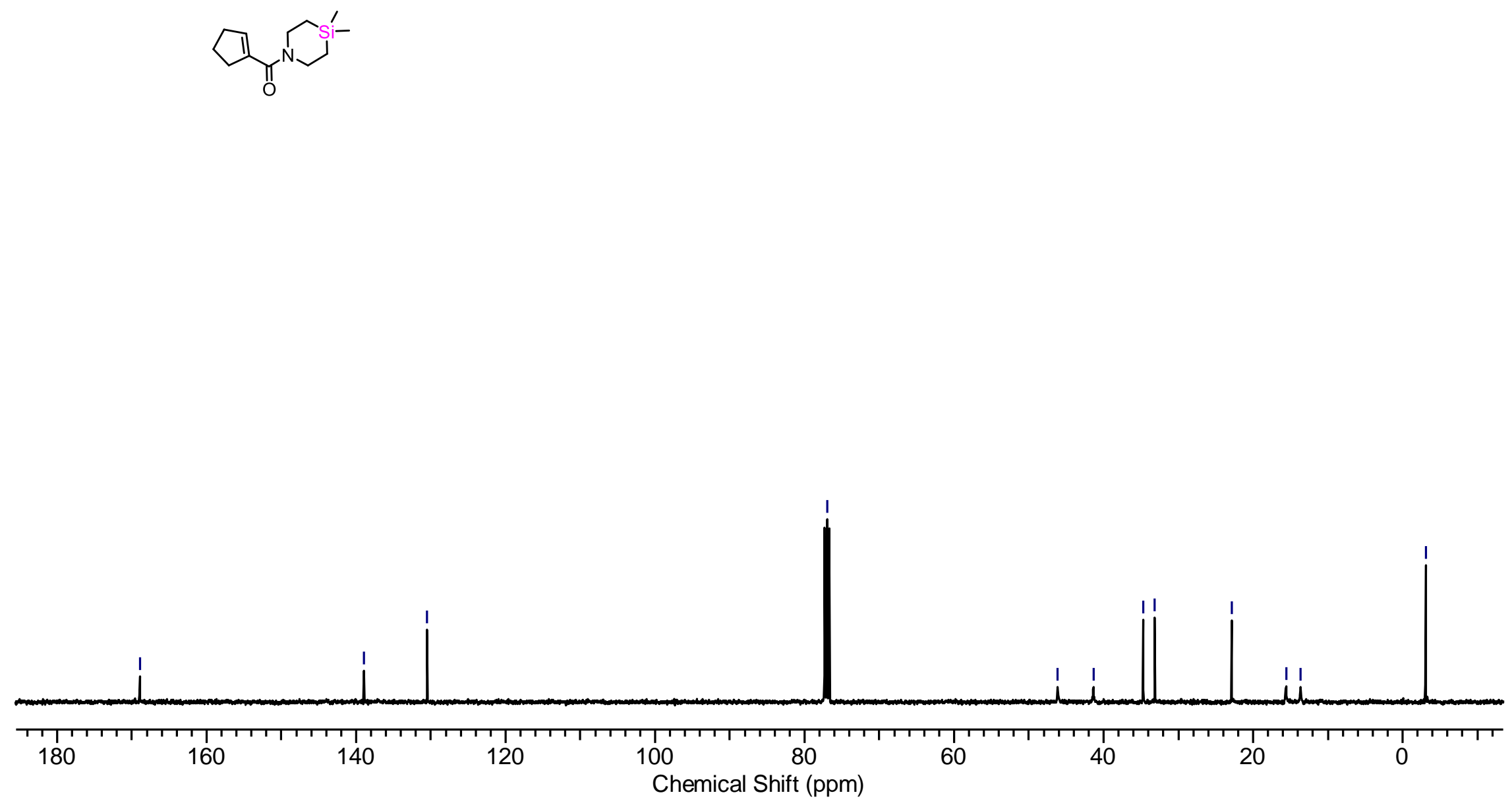


\section{Figure S11: ${ }^{1} \mathrm{H}$ NMR of 7 in $\mathrm{CDCl}_{3}(400 \mathrm{MHz})$}

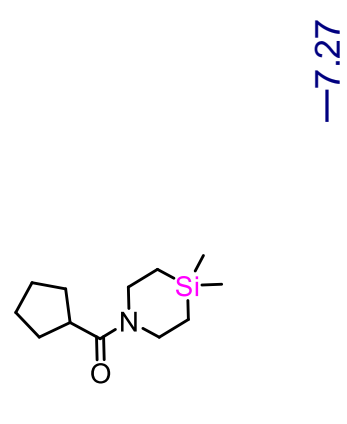

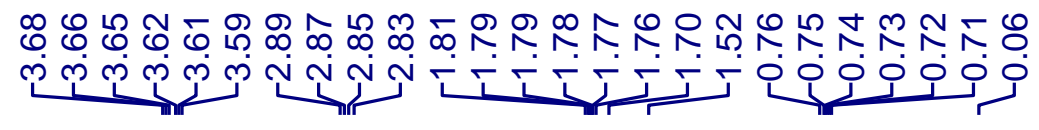

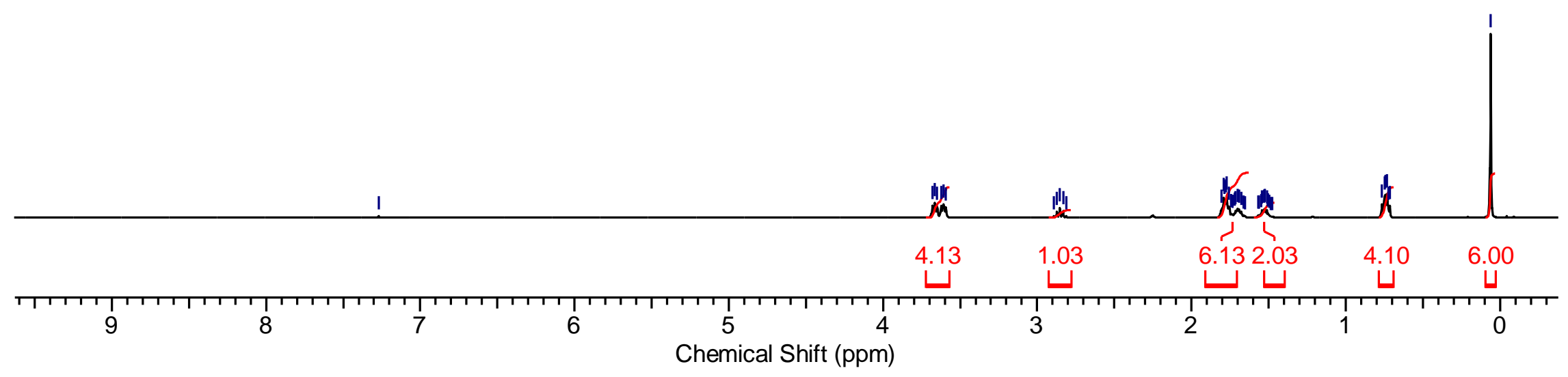




\section{Figure S12: ${ }^{13} \mathrm{C}$ NMR of 7 in $\mathrm{CDCl}_{3}(100 \mathrm{MHz})$}
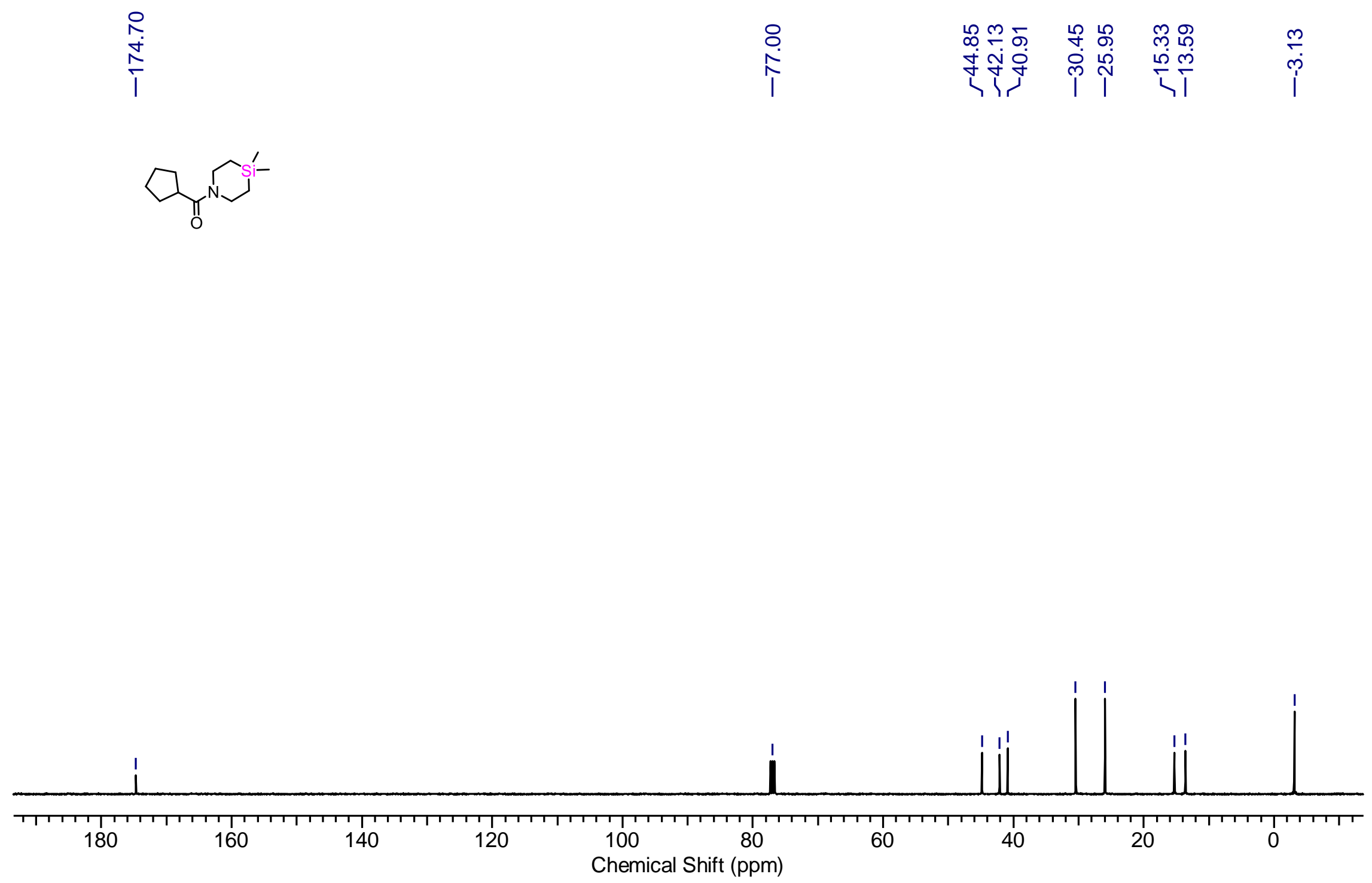


\section{Figure S13: ${ }^{1} \mathrm{H}$ NMR of 8 in $\mathrm{CDCl}_{3}(400 \mathrm{MHz})$}
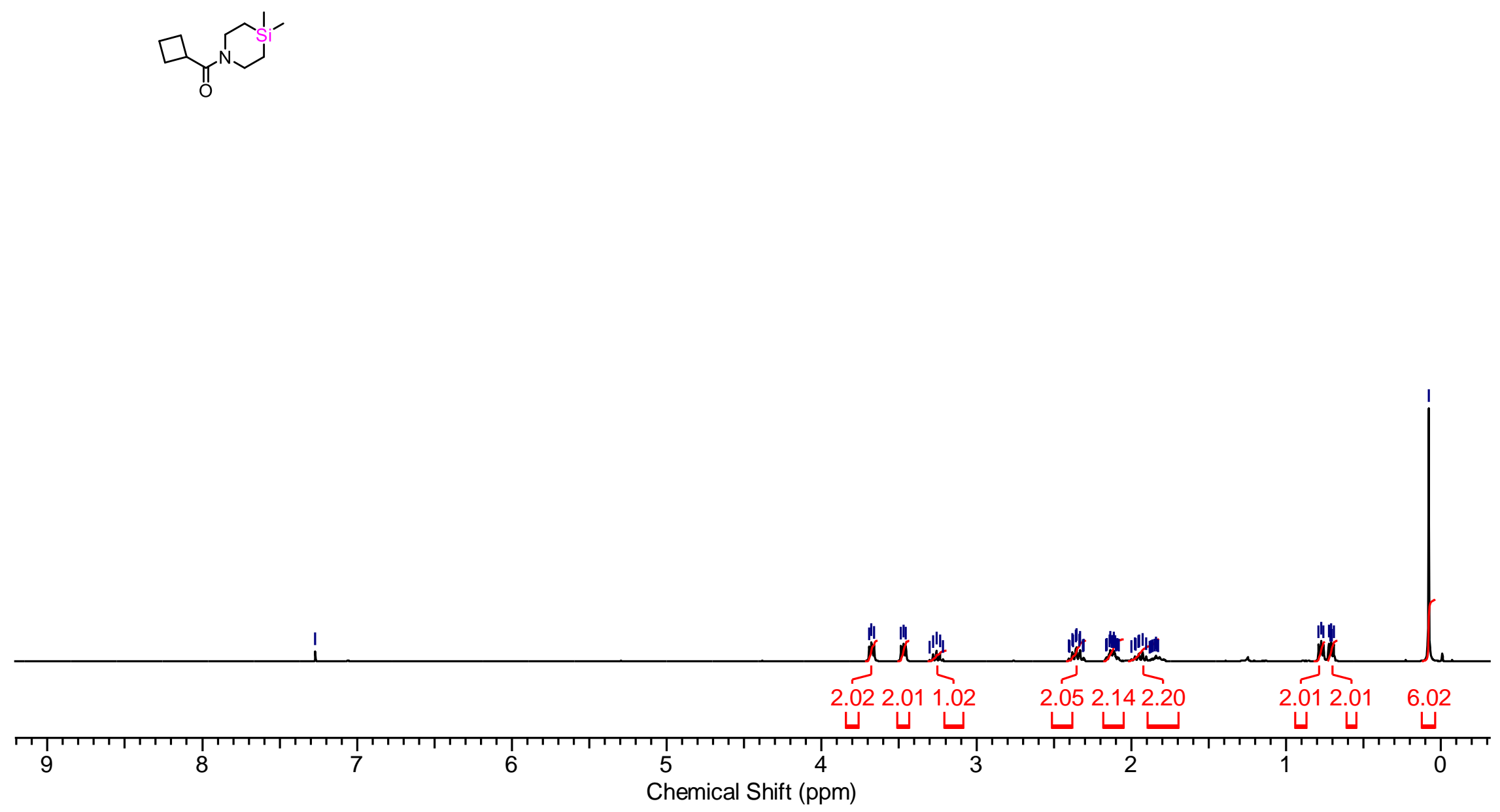


\section{Figure S14: ${ }^{13} \mathrm{C}$ NMR of 8 in $\mathrm{CDCl}_{3}(100 \mathrm{MHz})$}
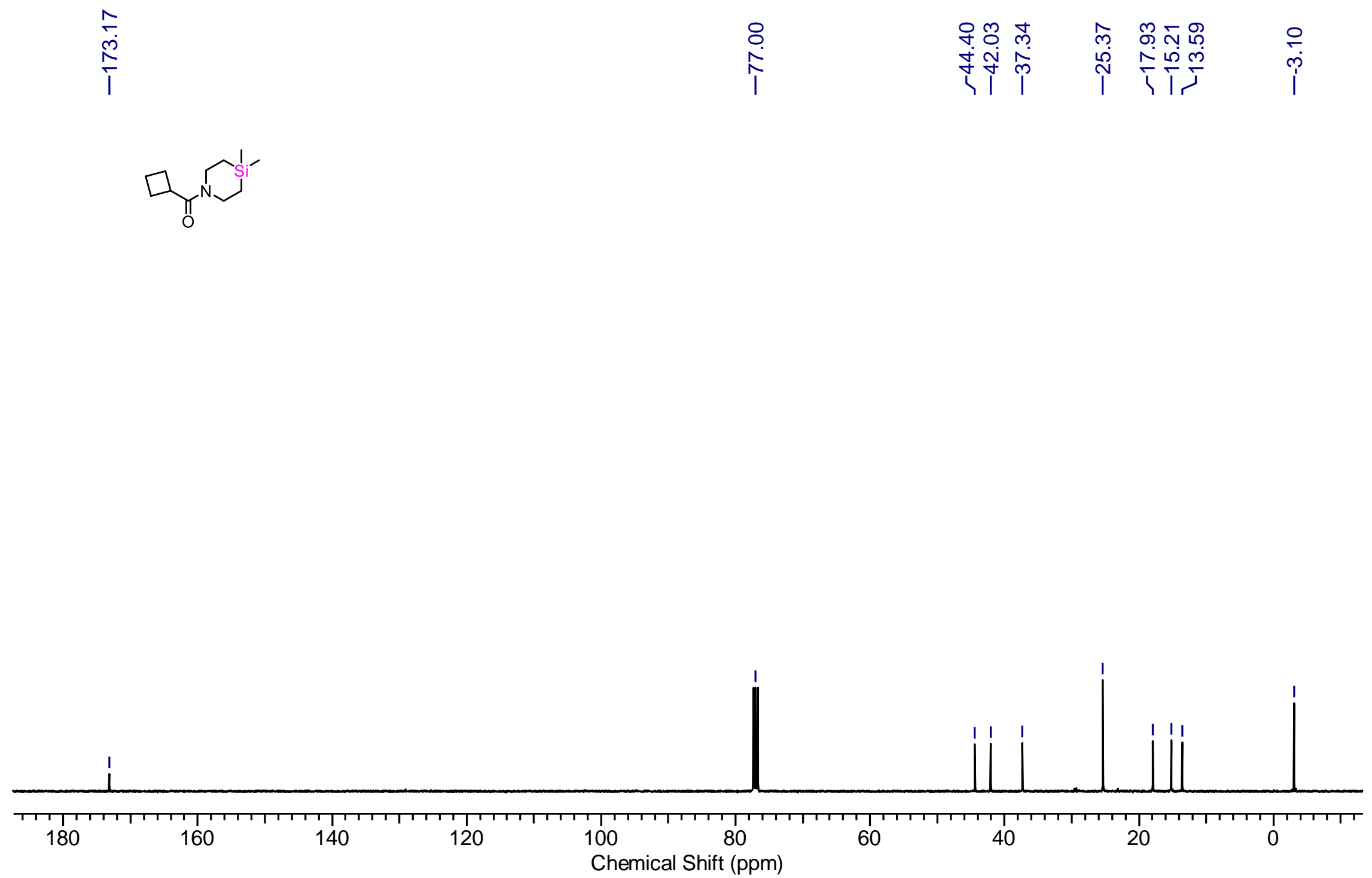


\section{Figure S15: ${ }^{1} \mathrm{H}$ NMR of 9 in $\mathrm{CDCl}_{3}(400 \mathrm{MHz})$}

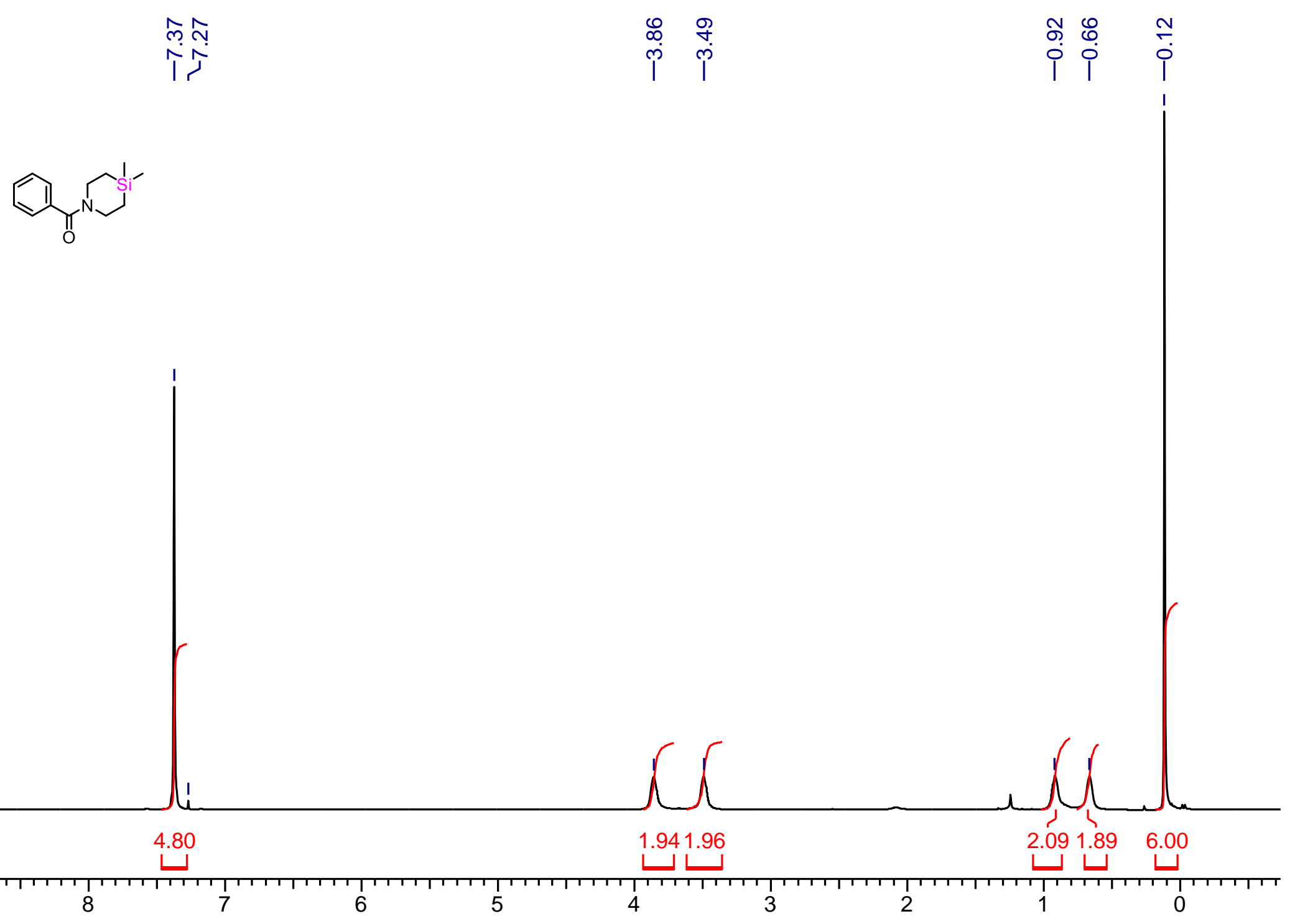




\section{Figure S16: ${ }^{13} \mathrm{C}$ NMR of 9 in $\mathrm{CDCl}_{3}(100 \mathrm{MHz})$}

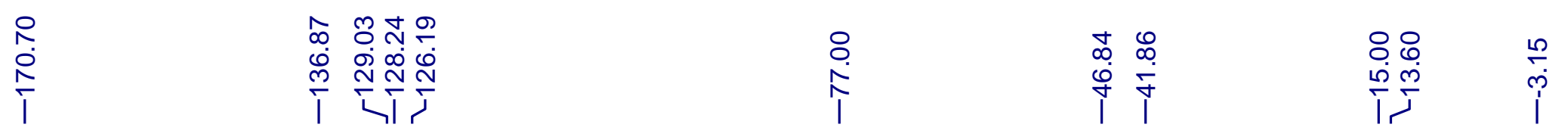
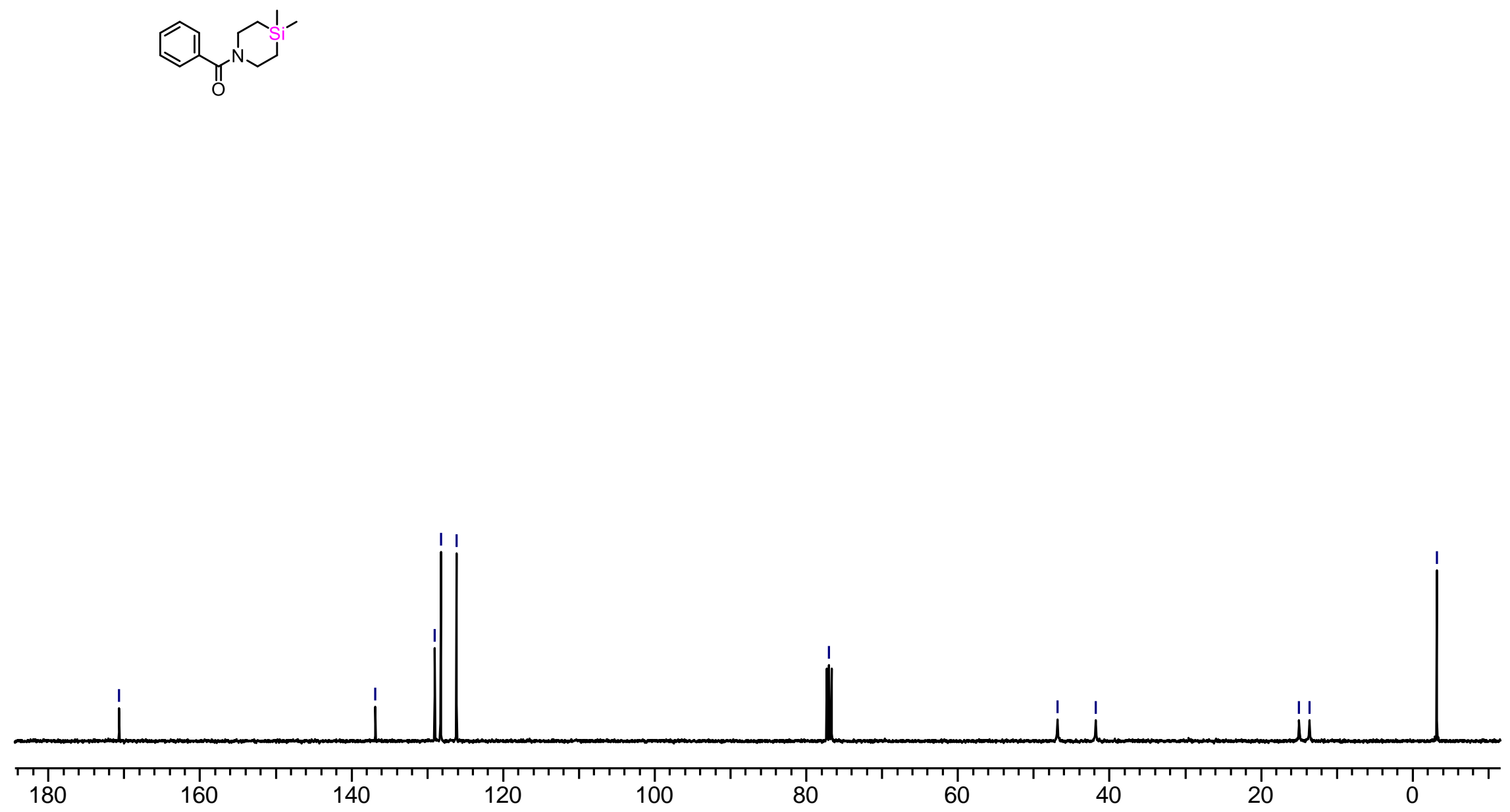


\section{Figure S17: ${ }^{1} \mathrm{H}$ NMR of 10 in $\mathrm{CDCl}_{3}(400 \mathrm{MHz})$}

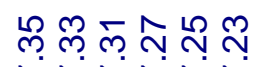

NNNNN

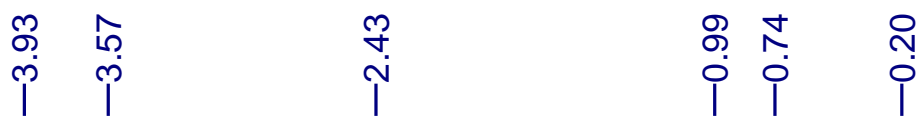
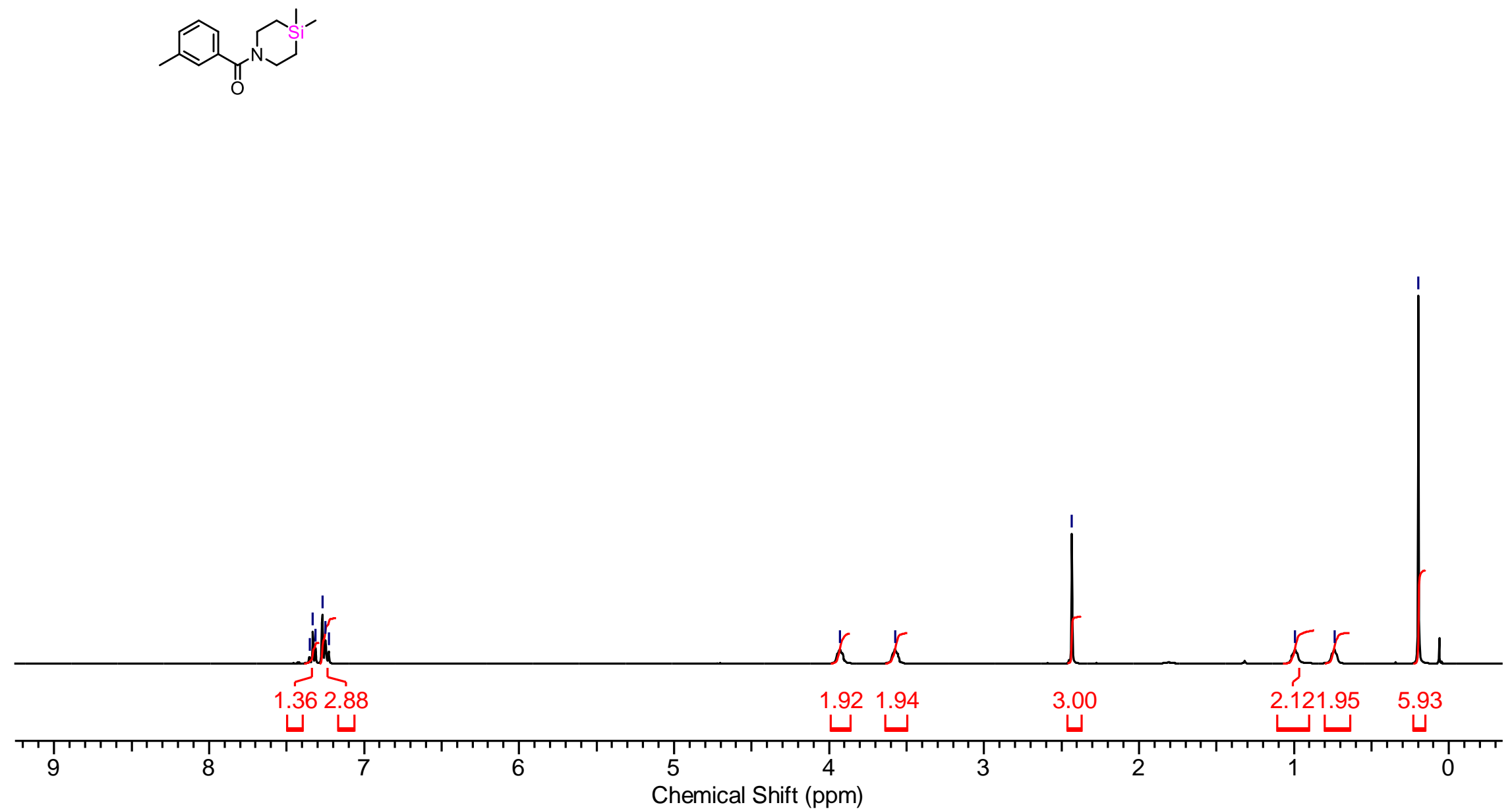


\section{Figure S18: ${ }^{13} \mathrm{C}$ NMR of 10 in $\mathrm{CDCl}_{3}(100 \mathrm{MHz})$}

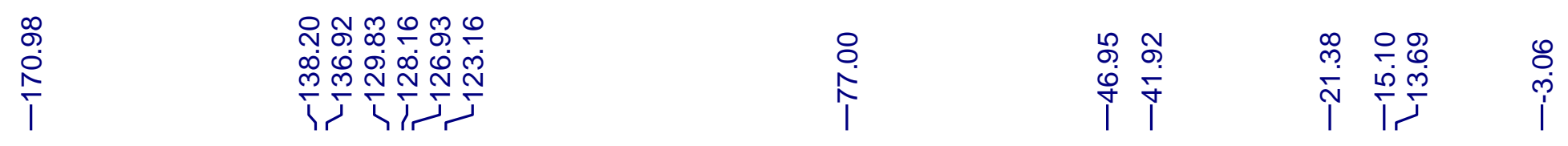
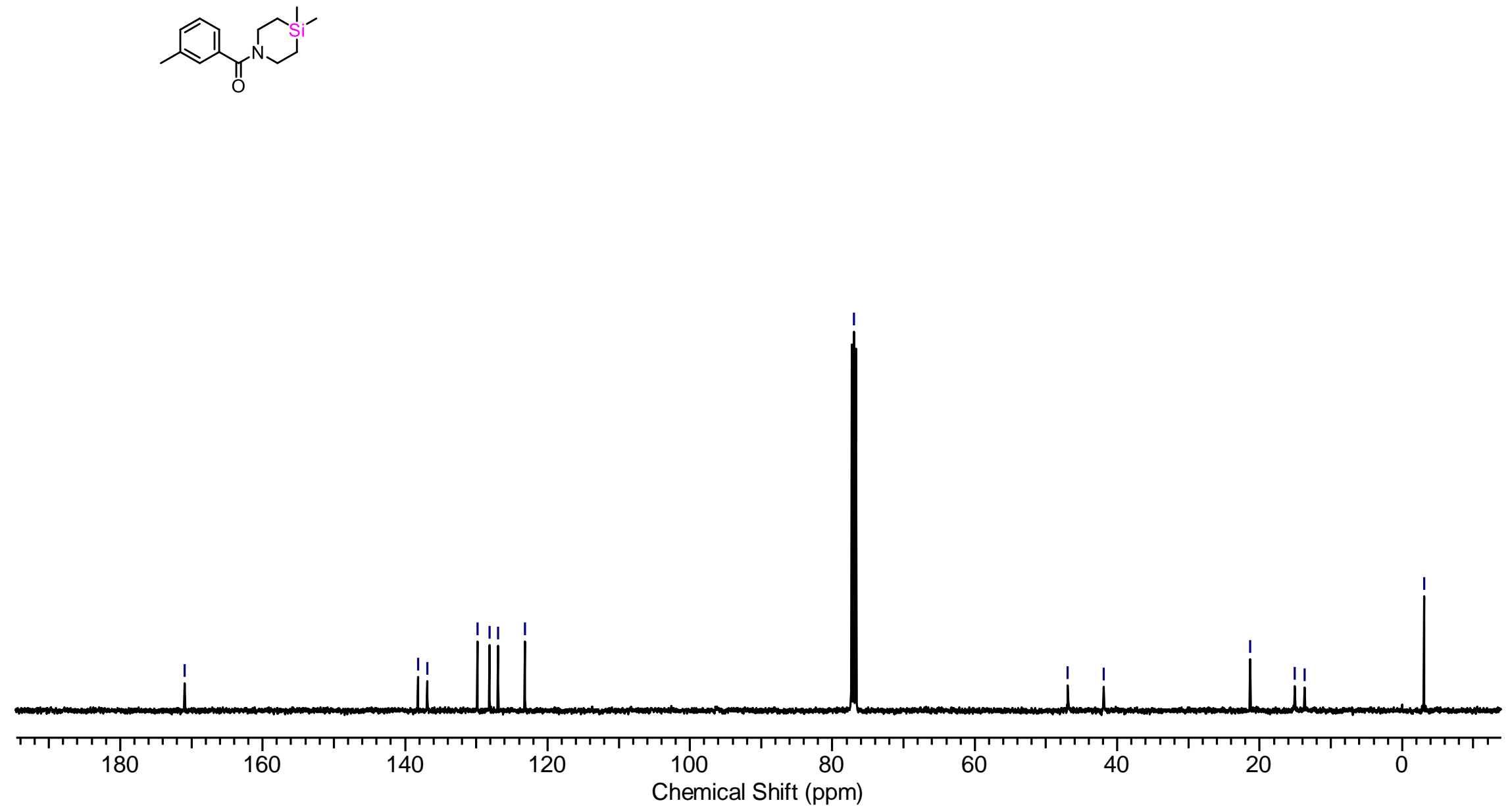


\section{Figure S19: ${ }^{1} \mathrm{H}$ NMR of 11 in $\mathrm{CDCl}_{3}(400 \mathrm{MHz})$}

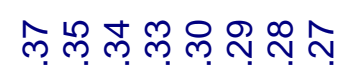

Nivitis

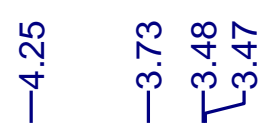

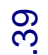

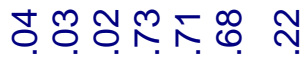

난ㅇ
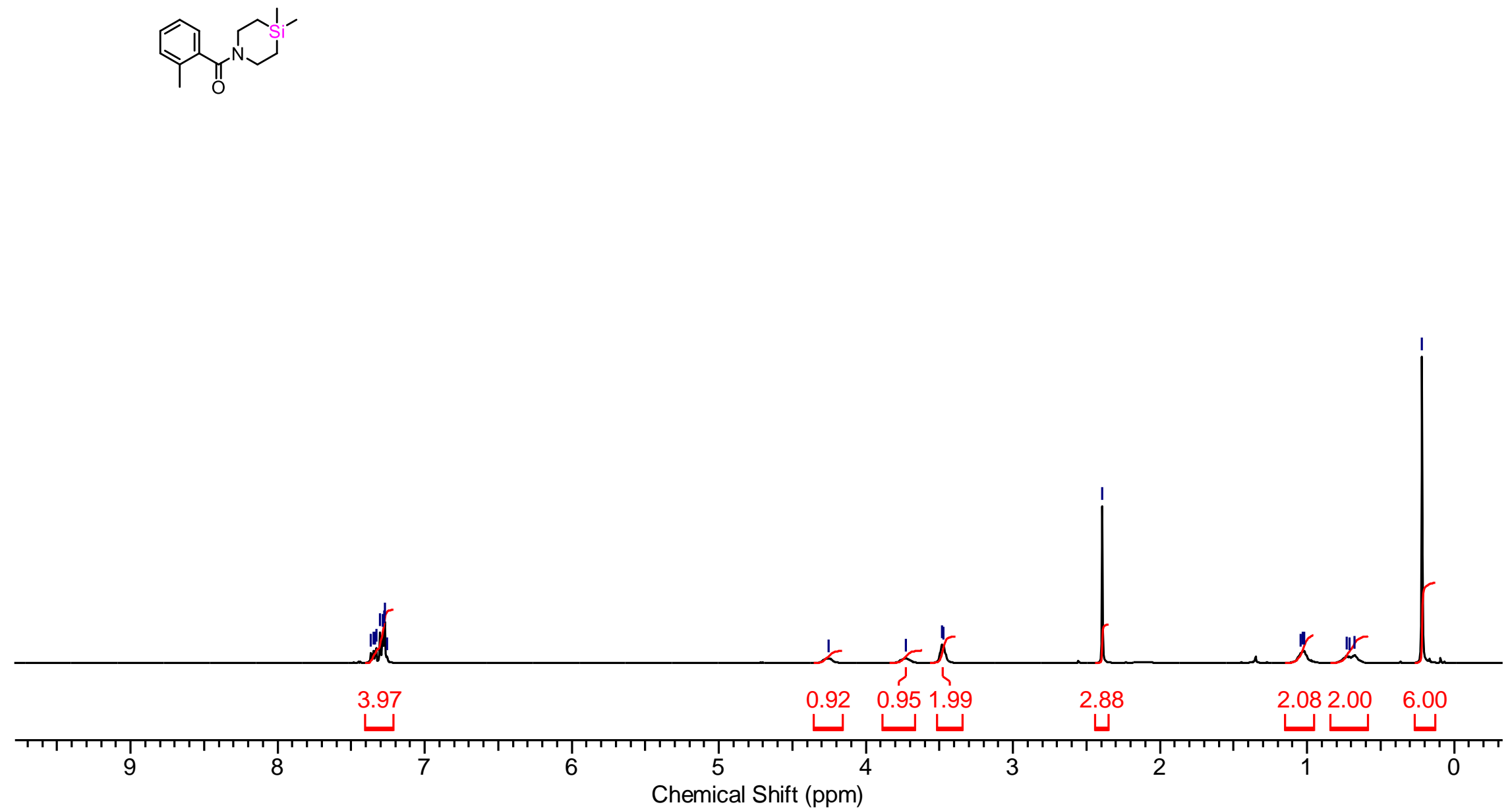


\section{Figure S20: ${ }^{13} \mathrm{C}$ NMR of 11 in $\mathrm{CDCl}_{3}(100 \mathrm{MHz})$}

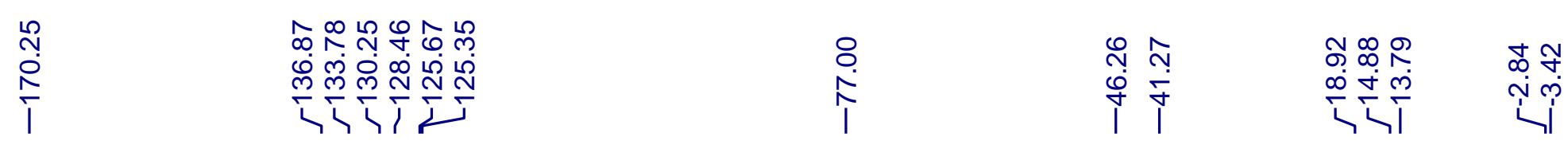
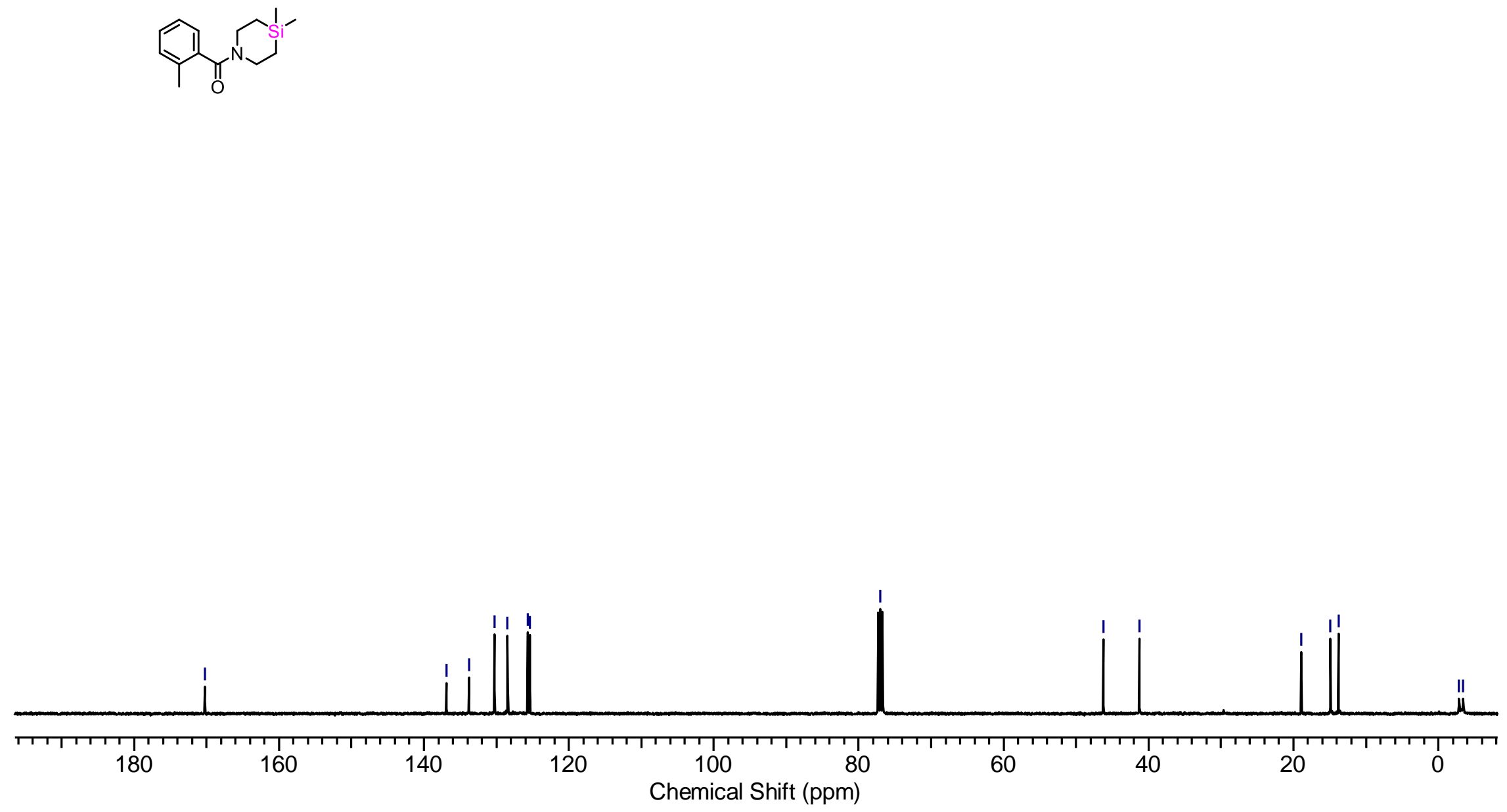


\section{Figure S21: ${ }^{1} \mathrm{H}$ NMR of 12 in $\mathrm{CDCl}_{3}(400 \mathrm{MHz})$}

ర్లె

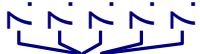

$\begin{array}{ll}\infty & 8 \\ \stackrel{p}{p} & \stackrel{p}{1}\end{array}$

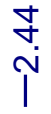

\begin{tabular}{ll}
1 & 0 \\
0 & 1 \\
\hline & 0
\end{tabular}

Nิ
i
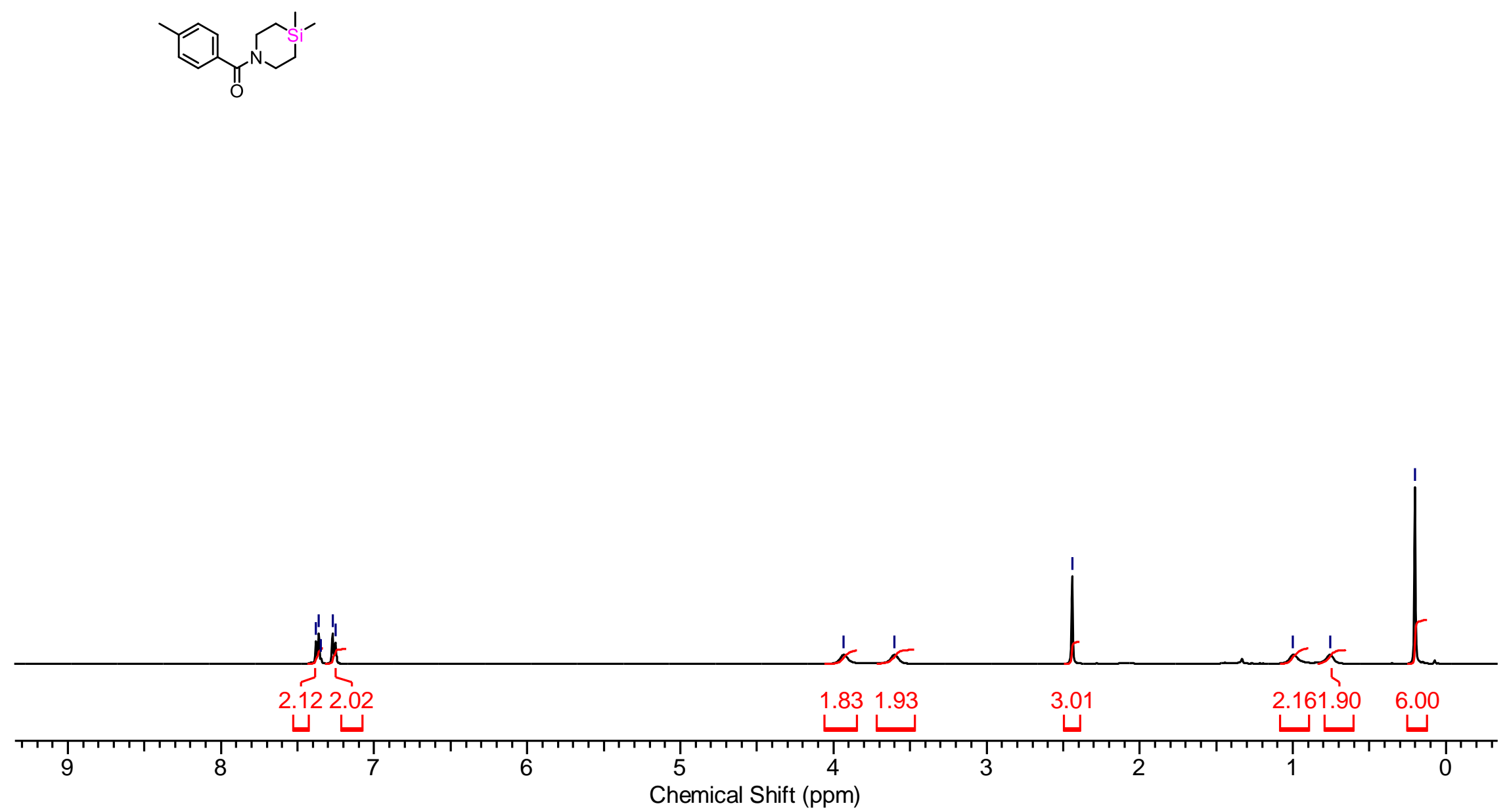


\section{Figure S22: ${ }^{13} \mathrm{C}$ NMR of 12 in $\mathrm{CDCl}_{3}(100 \mathrm{MHz})$}

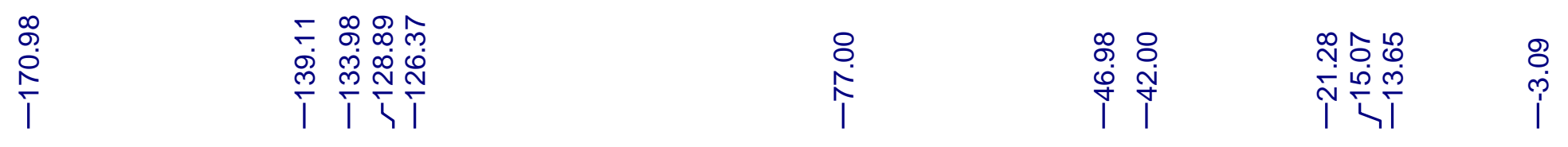
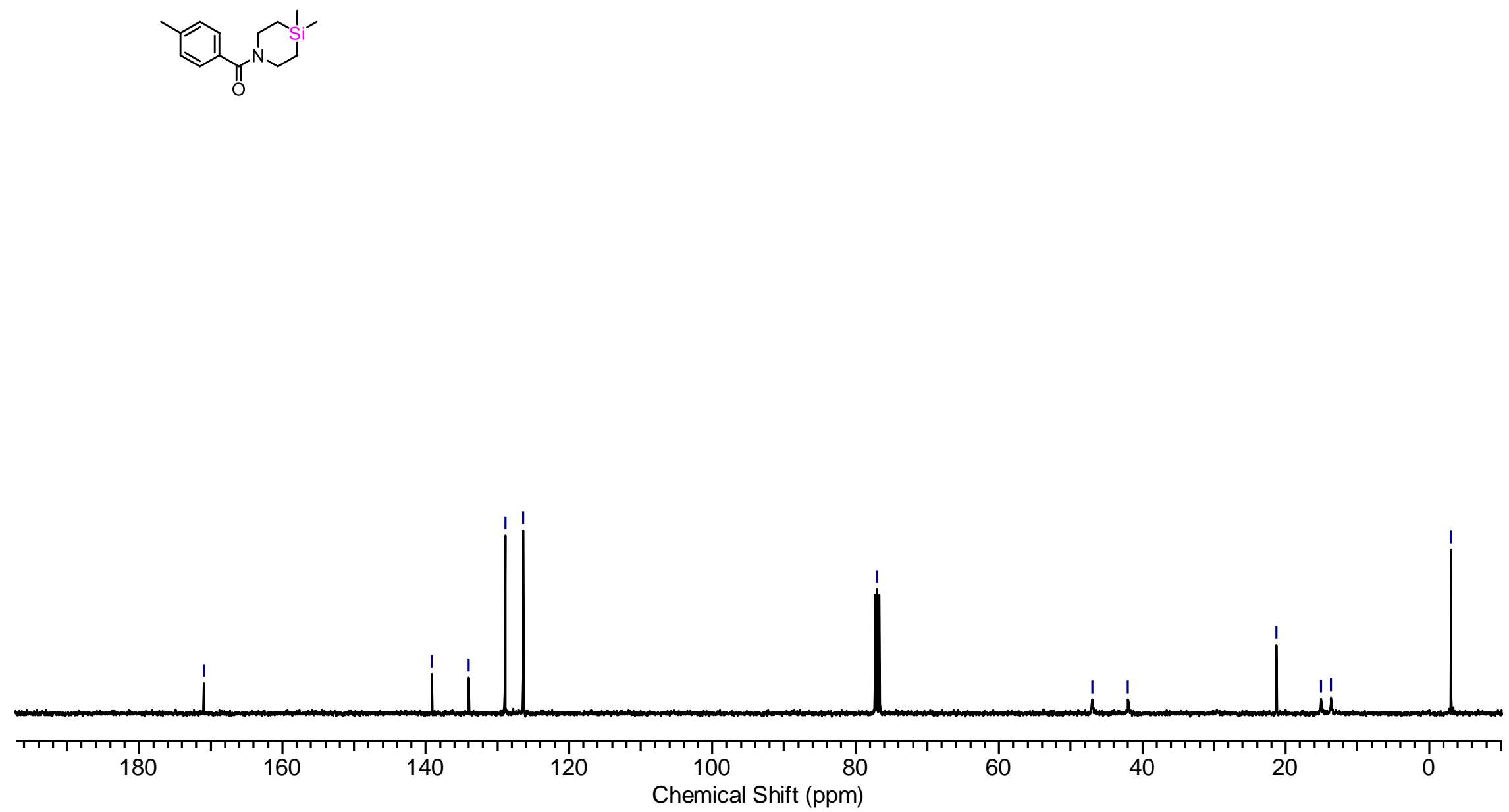


\section{Figure S23: ${ }^{1} \mathrm{H}$ NMR of 13 in $\mathrm{CDCl}_{3}(400 \mathrm{MHz})$}

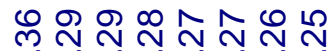

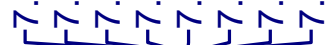

$\underbrace{1}_{\mathrm{Cl}}$

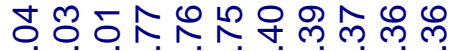

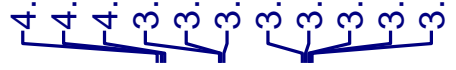

ن

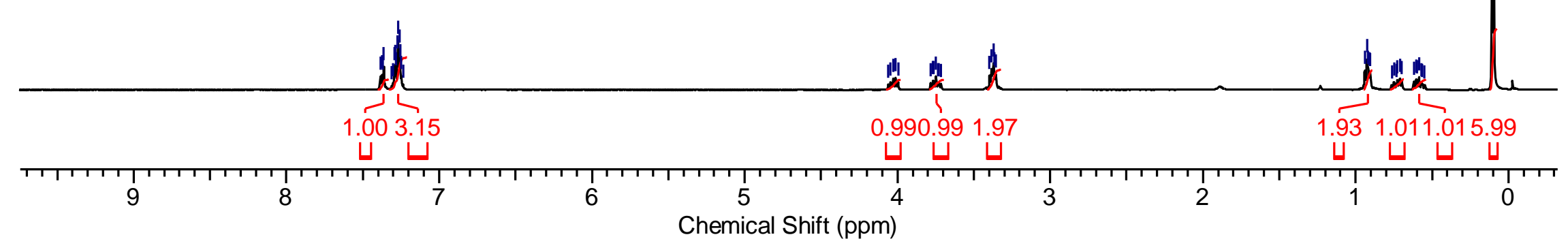




\section{Figure S24: ${ }^{13} \mathrm{C}$ NMR of 13 in $\mathrm{CDCl}_{3}(100 \mathrm{MHz})$}

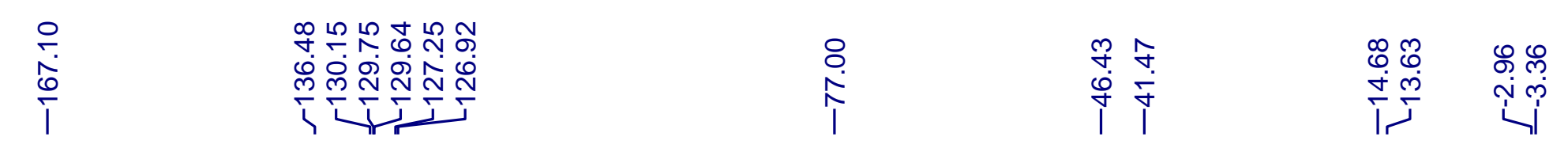
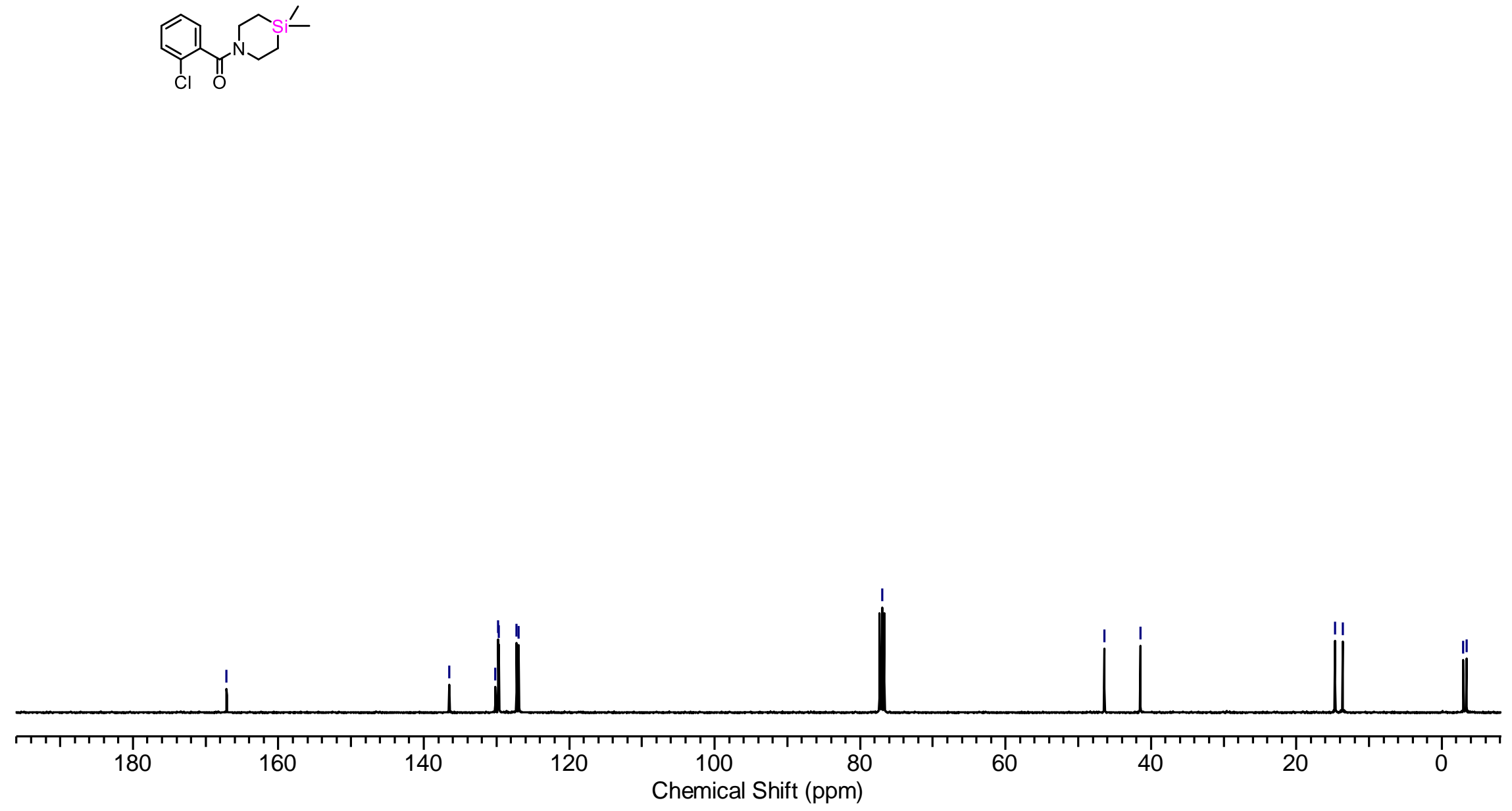


\section{Figure S25: ${ }^{1} \mathrm{H}$ NMR of 14 in $\mathrm{CDCl}_{3}(400 \mathrm{MHz})$}

岗

손소

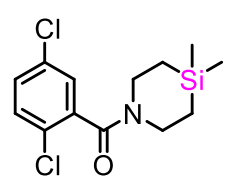

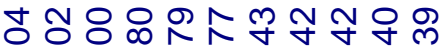

ن

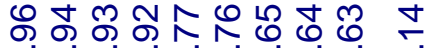

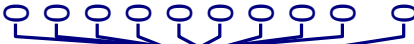

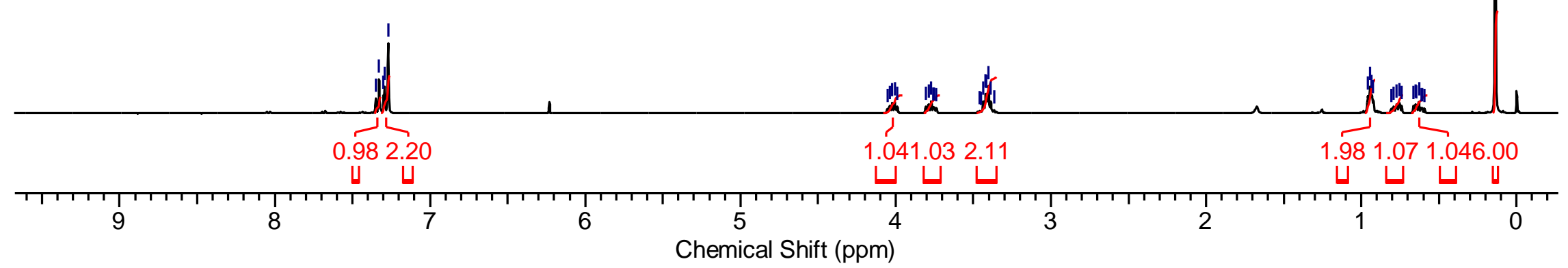




\section{Figure S26: ${ }^{13} \mathrm{C}$ NMR of 14 in $\mathrm{CDCl}_{3}(100 \mathrm{MHz})$}

\begin{tabular}{|c|c|c|c|}
\hline 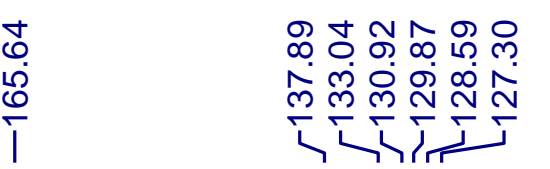 & $\underset{\substack{0 \\
i}}{\stackrel{0}{i}}$ & 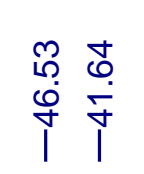 & 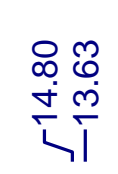 \\
\hline
\end{tabular}
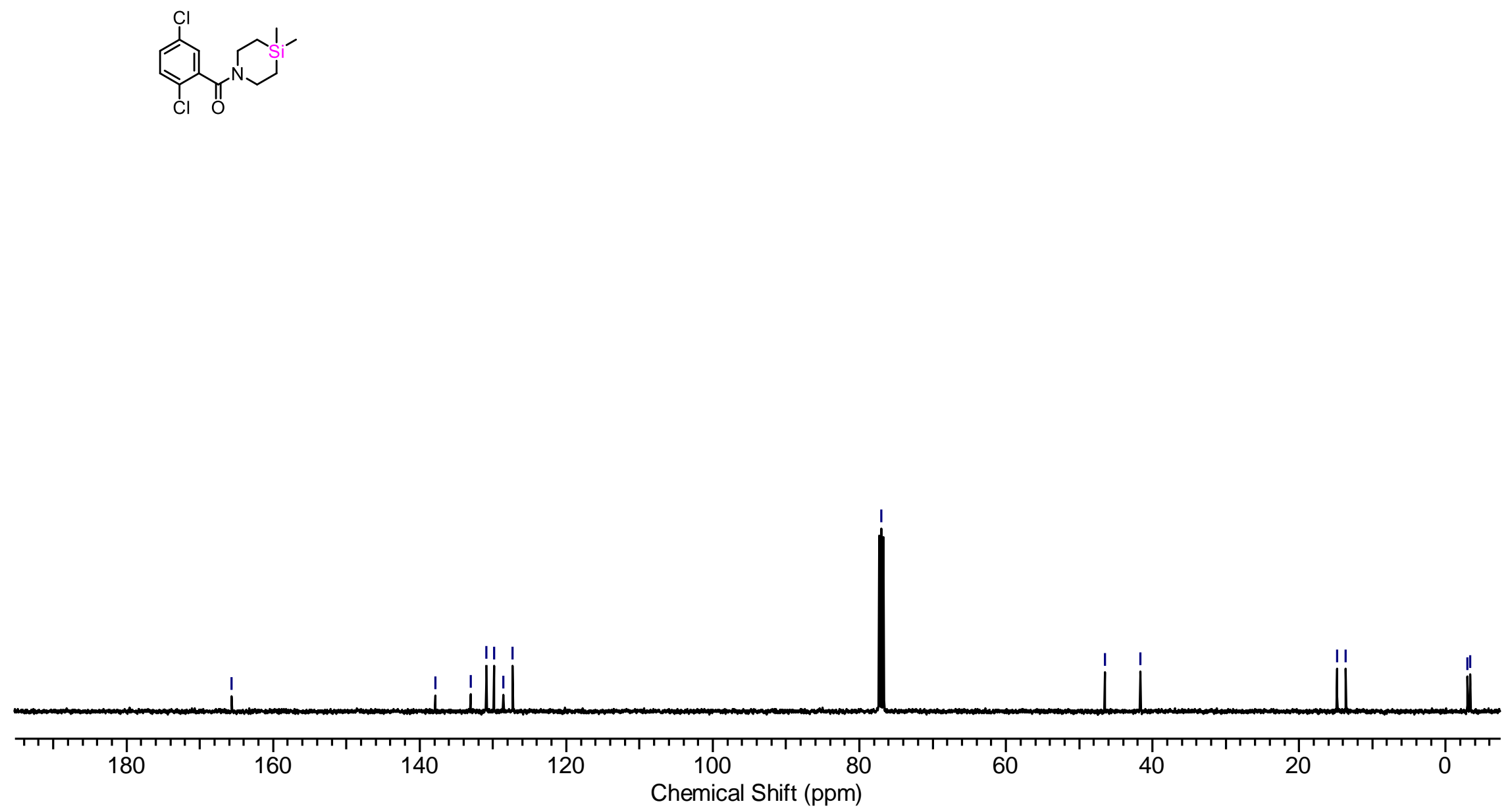


\section{Figure S27: ${ }^{1} \mathrm{H}$ NMR of 15 in $\mathrm{CDCl}_{3}(400 \mathrm{MHz})$}

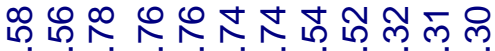

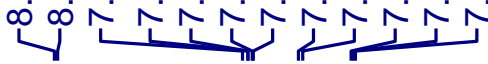

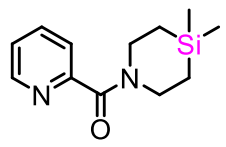

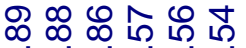

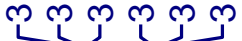

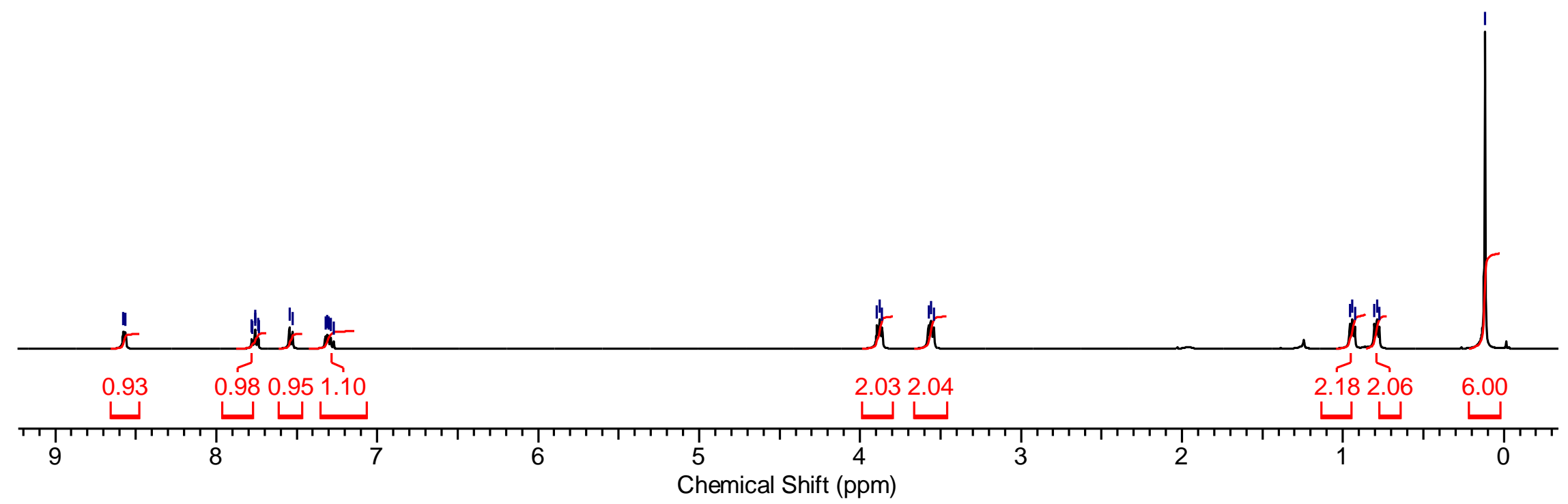




\section{Figure S28: ${ }^{13} \mathrm{C}$ NMR of 15 in $\mathrm{CDCl}_{3}(100 \mathrm{MHz})$}

$$
\text { Hit }
$$

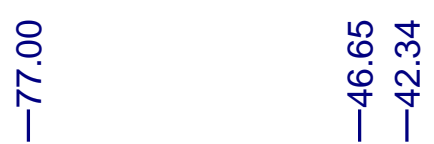

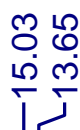
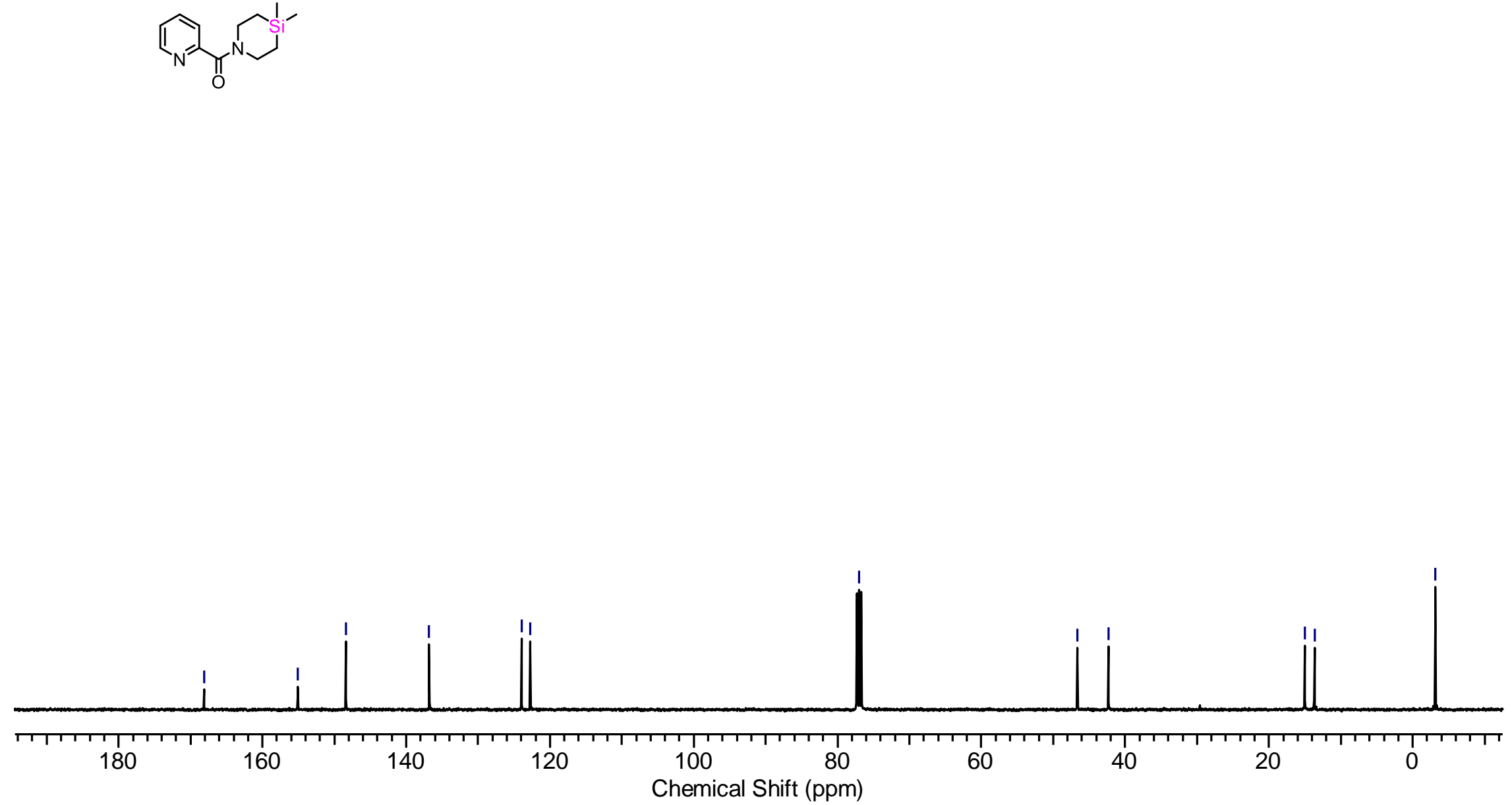


\section{Figure S29: ${ }^{1} \mathrm{H}$ NMR of 16 in $\mathrm{CDCl}_{3}(400 \mathrm{MHz})$}

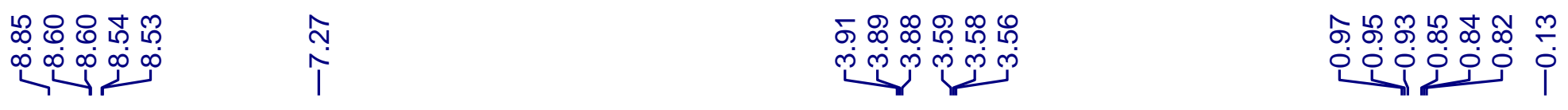
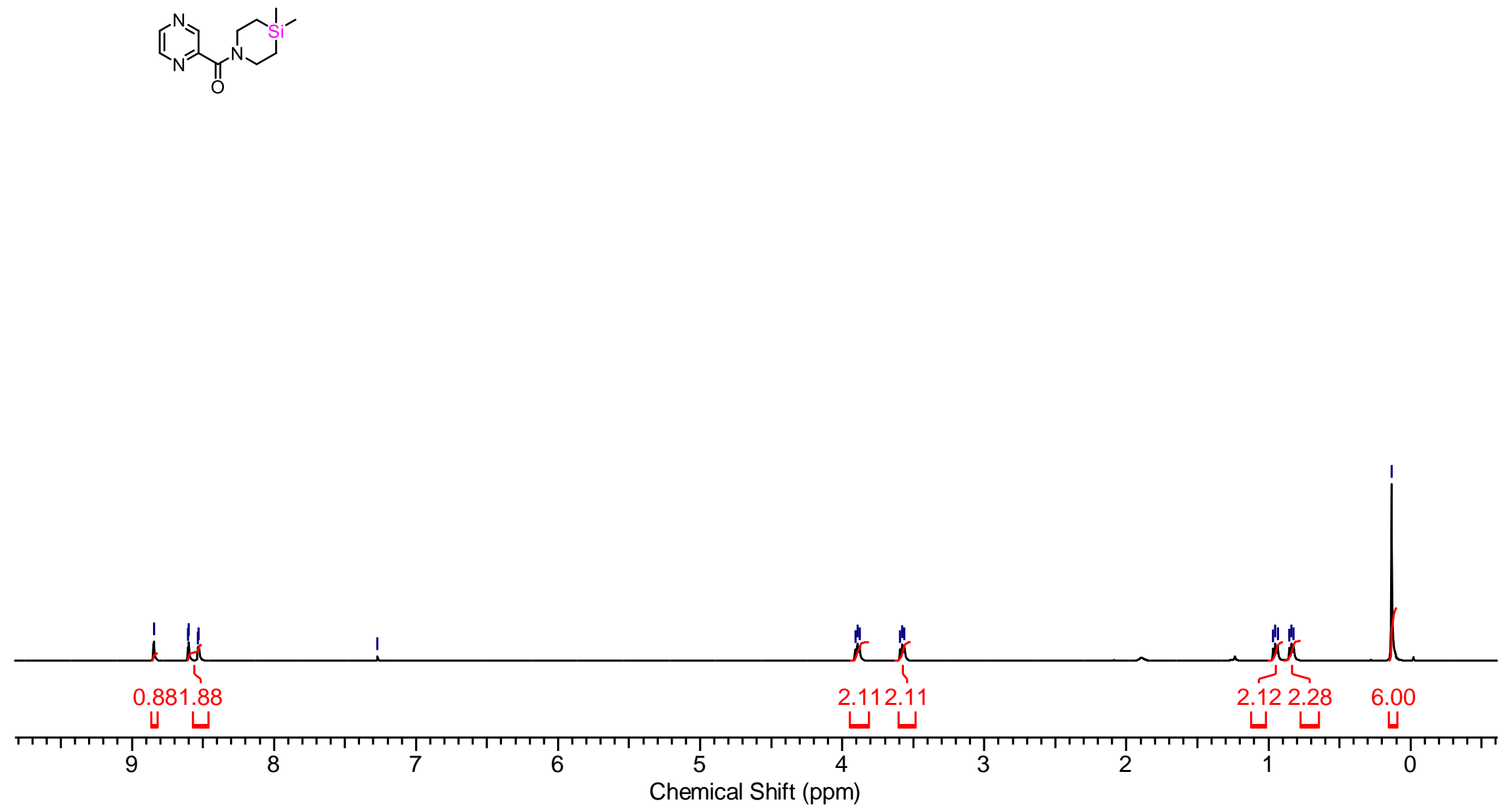


\section{Figure S30: ${ }^{13} \mathrm{C}$ NMR of 16 in $\mathrm{CDCl}_{3}(100 \mathrm{MHz})$}
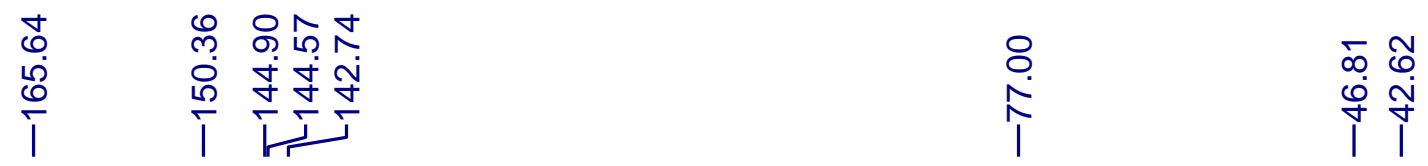

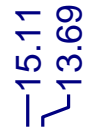

ㄴ
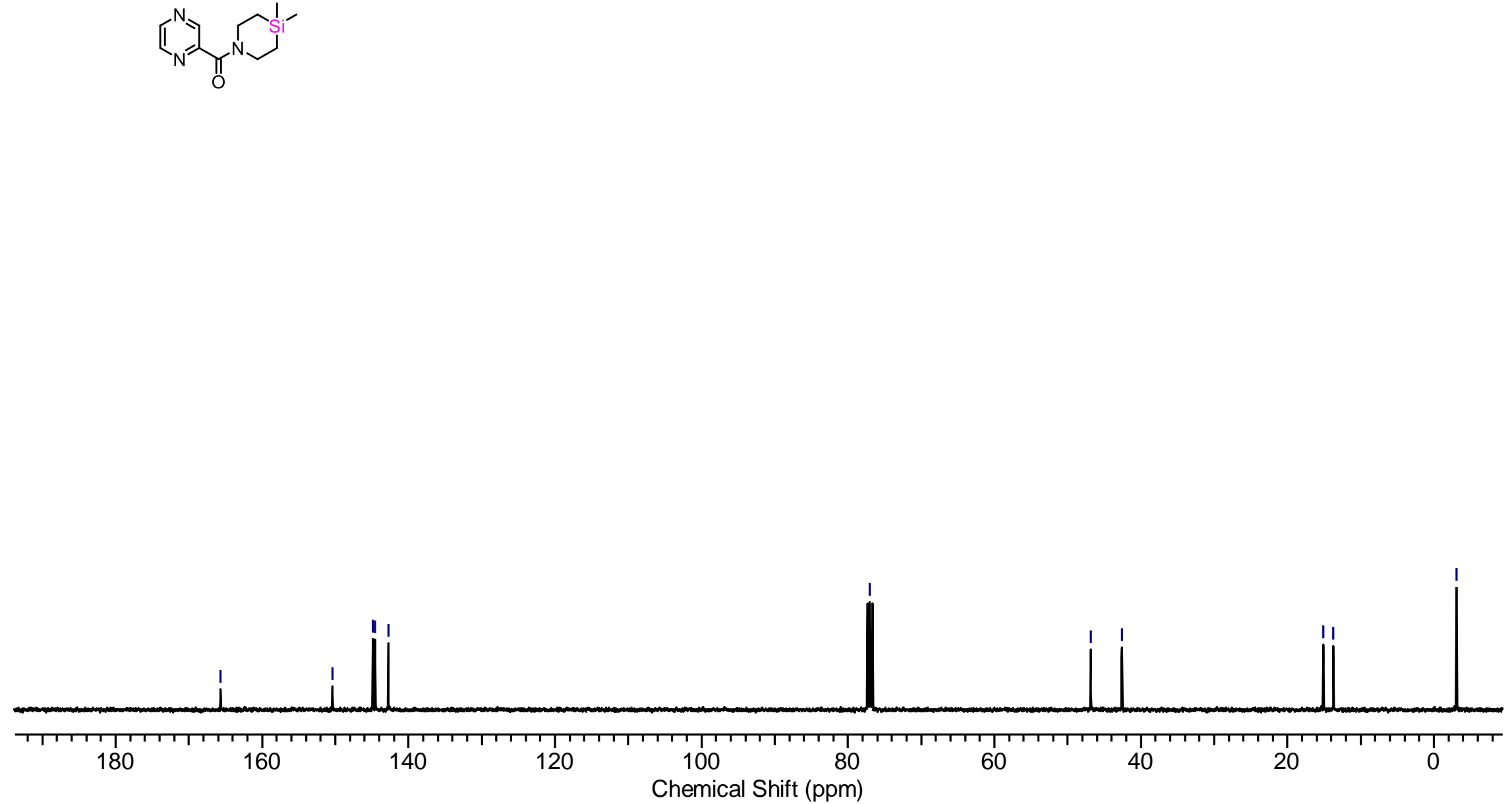


\section{Figure S31: ${ }^{1} \mathrm{H}$ NMR of 17 in $\mathrm{CDCl}_{3}(400 \mathrm{MHz})$}

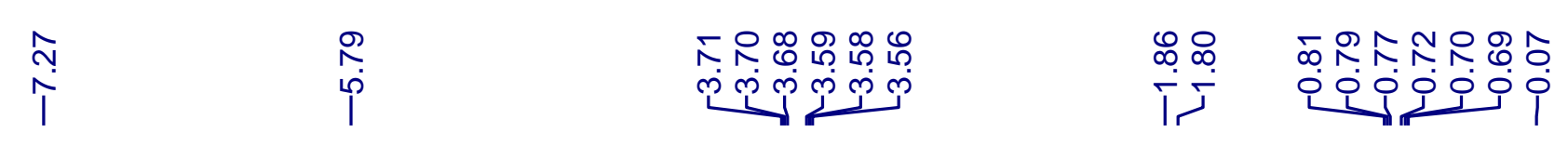
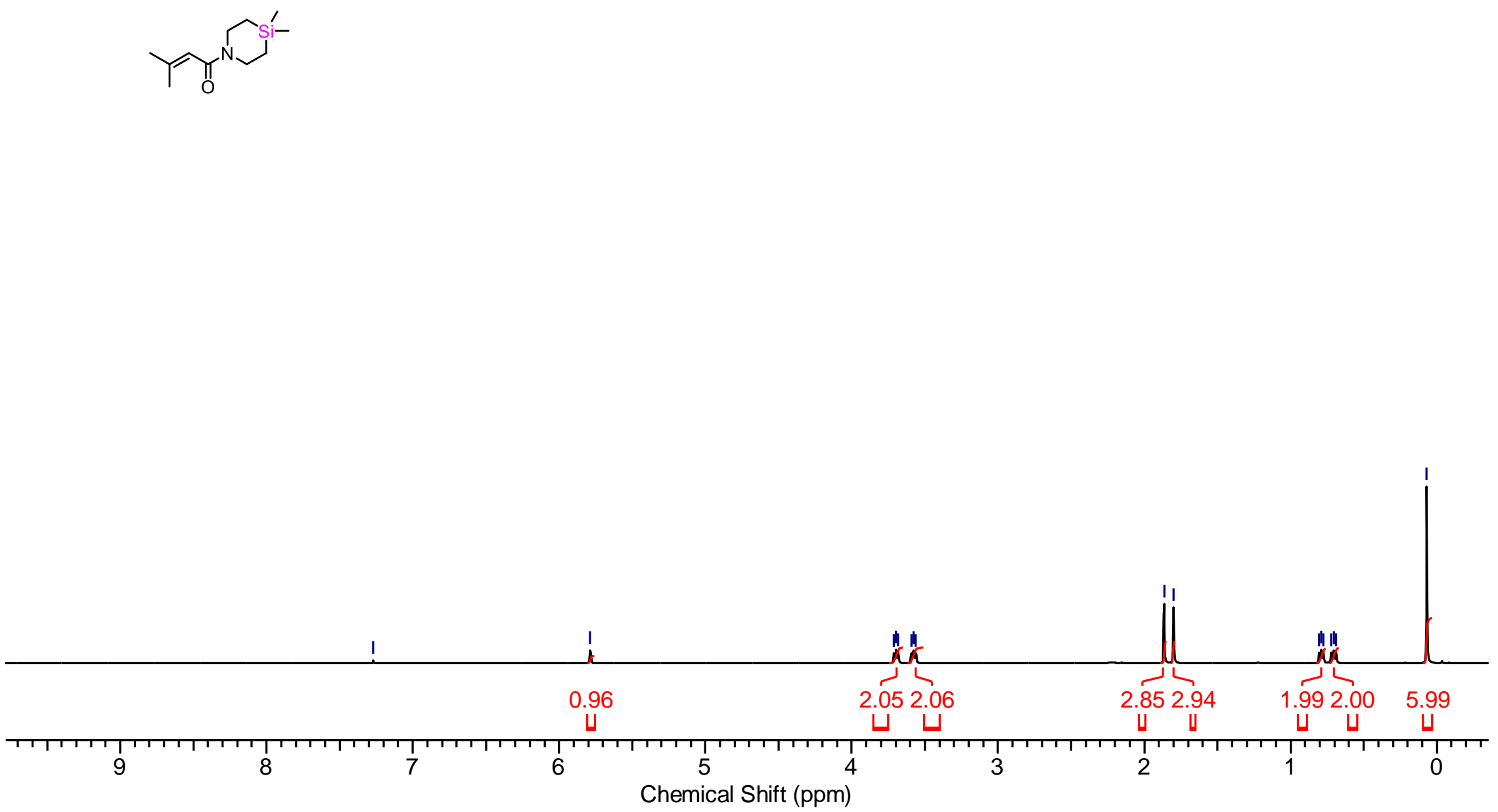


\section{Figure S32: ${ }^{13} \mathrm{C}$ NMR of 17 in $\mathrm{CDCl}_{3}(100 \mathrm{MHz})$}

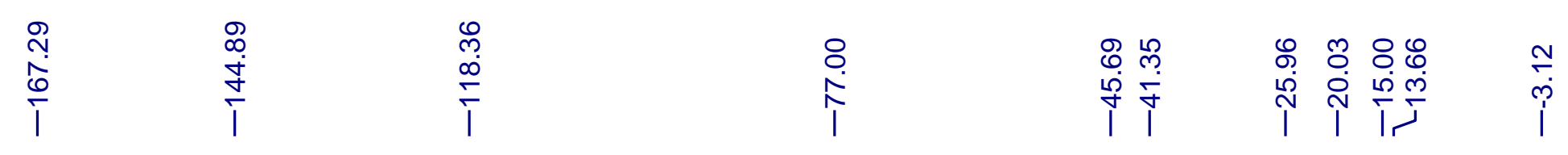
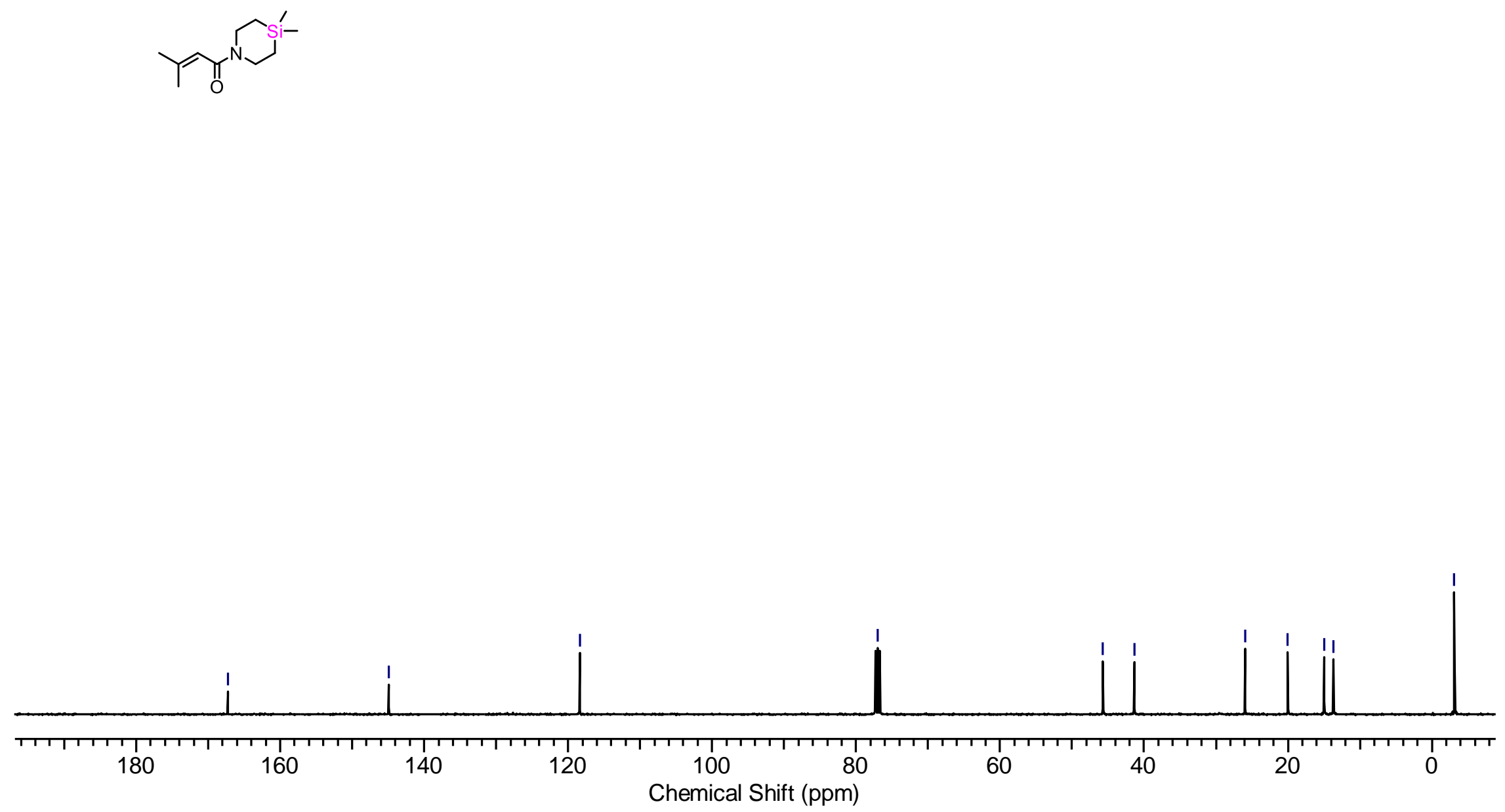


\section{Figure S33: ${ }^{1} \mathrm{H}$ NMR of 18 in $\mathrm{CDCl}_{3}(400 \mathrm{MHz})$}

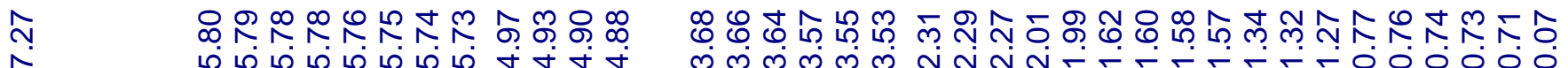

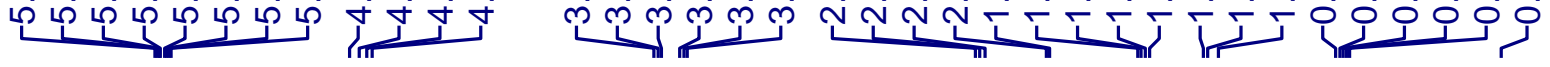
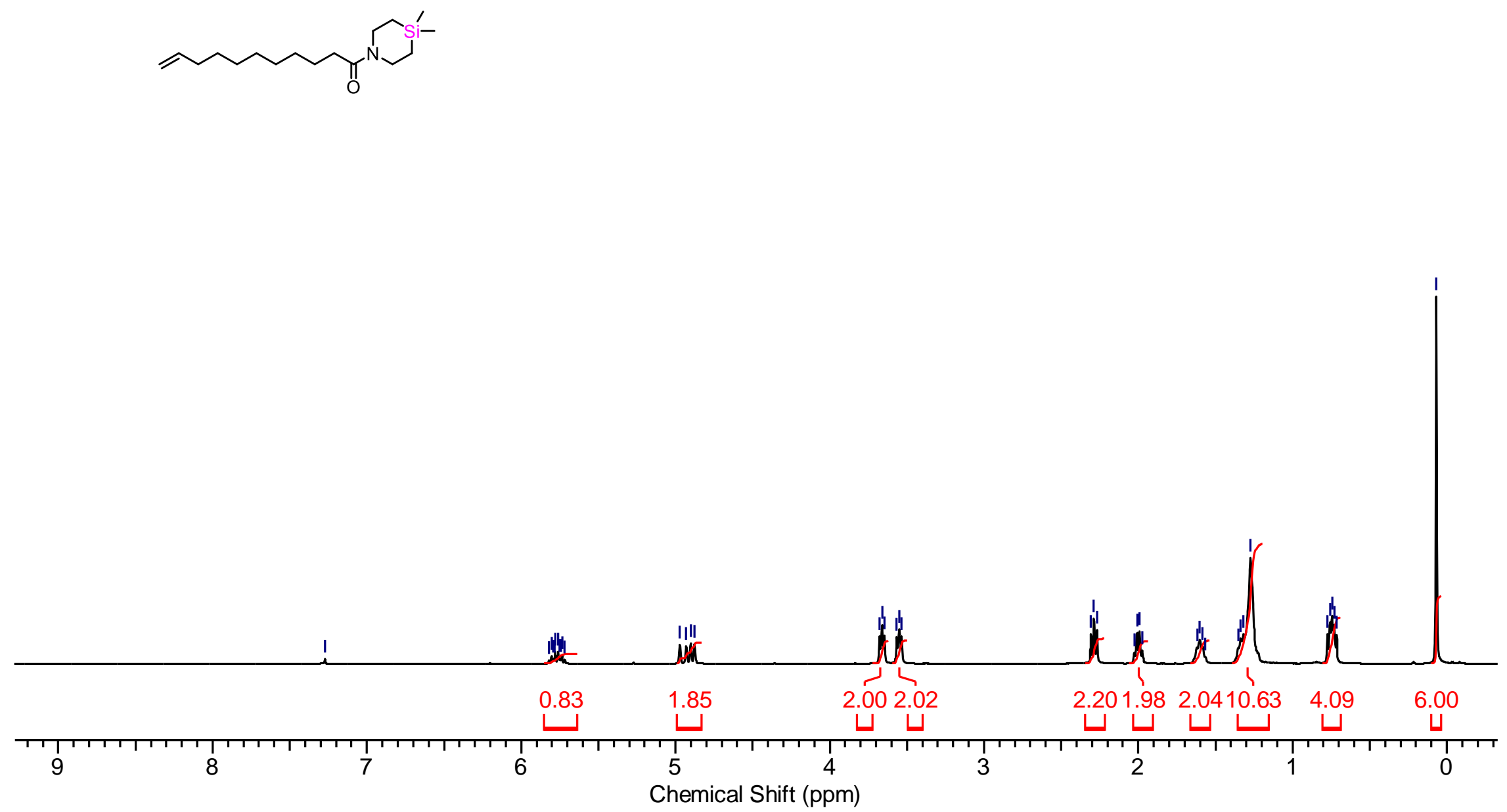


\section{Figure S34: ${ }^{13} \mathrm{C}$ NMR of 18 in $\mathrm{CDCl}_{3}(100 \mathrm{MHz})$}

\begin{tabular}{|c|c|c|c|c|}
\hline 立 & $\begin{array}{l}\text { t. } \\
\text { Oे } \\
\text { m }\end{array}$ & $\begin{array}{l}8 \\
+ \\
+\end{array}$ & $\underset{\substack{8 \\
i}}{i}$ & 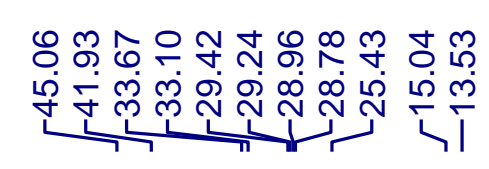 \\
\hline
\end{tabular}
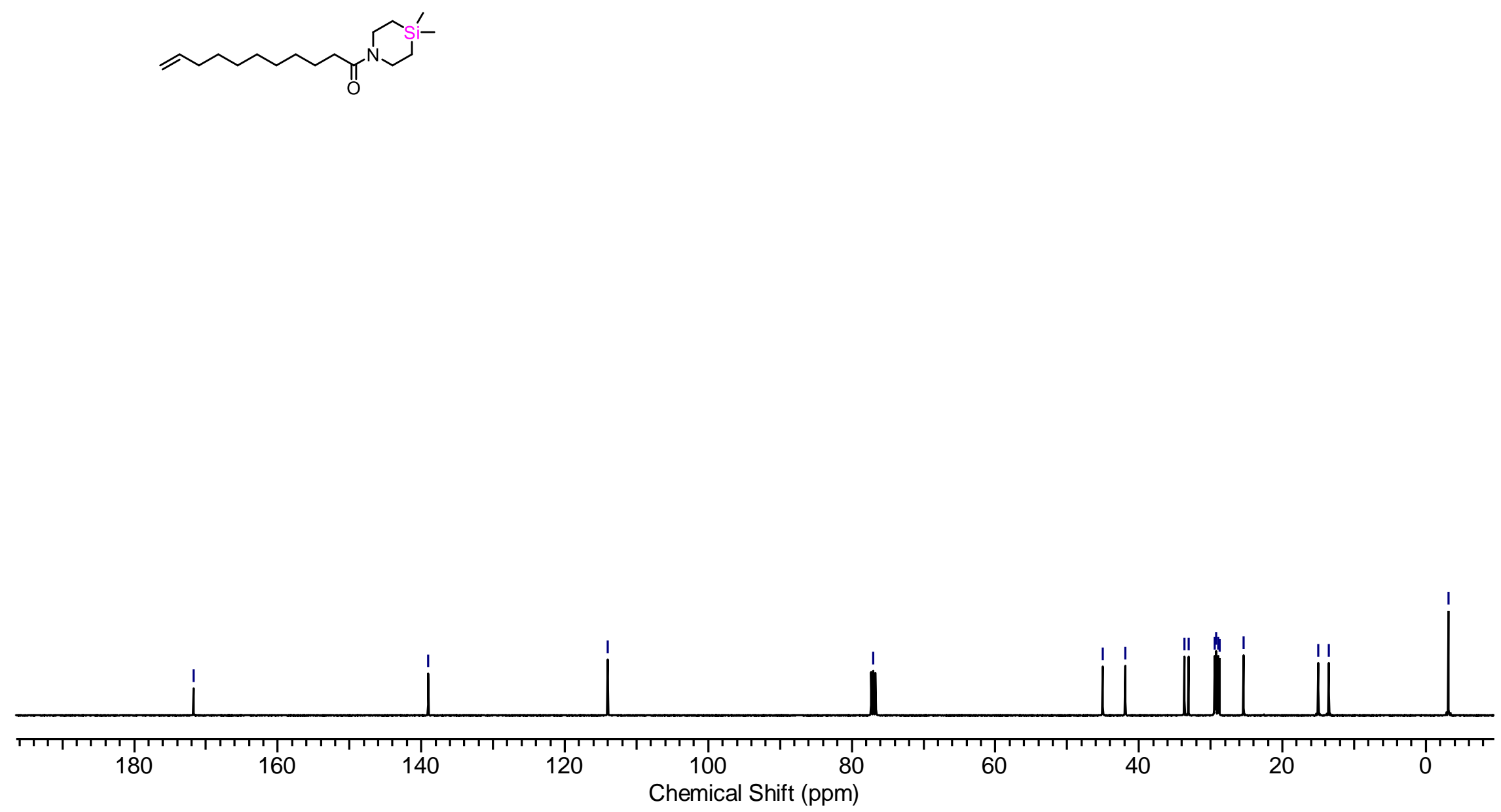


\section{Figure S35: ${ }^{1} \mathrm{H}$ NMR of 19 in $\mathrm{CDCl}_{3}(400 \mathrm{MHz})$}

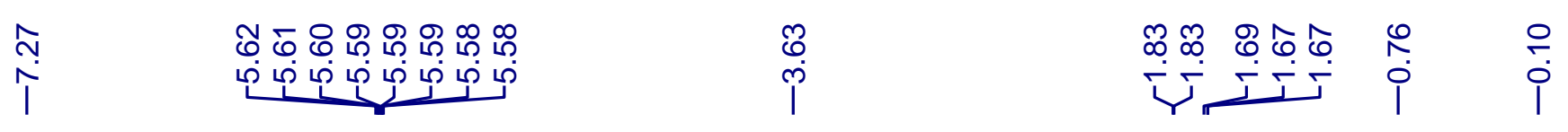<smiles>[V][Te]</smiles>

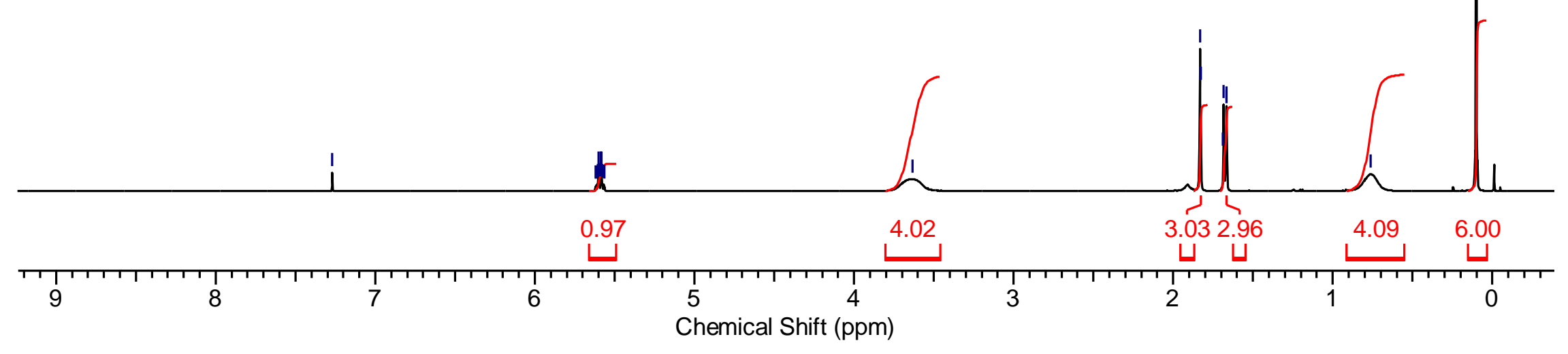




\section{Figure S36: ${ }^{13} \mathrm{C}$ NMR of 19 in $\mathrm{CDCl}_{3}(100 \mathrm{MHz})$}
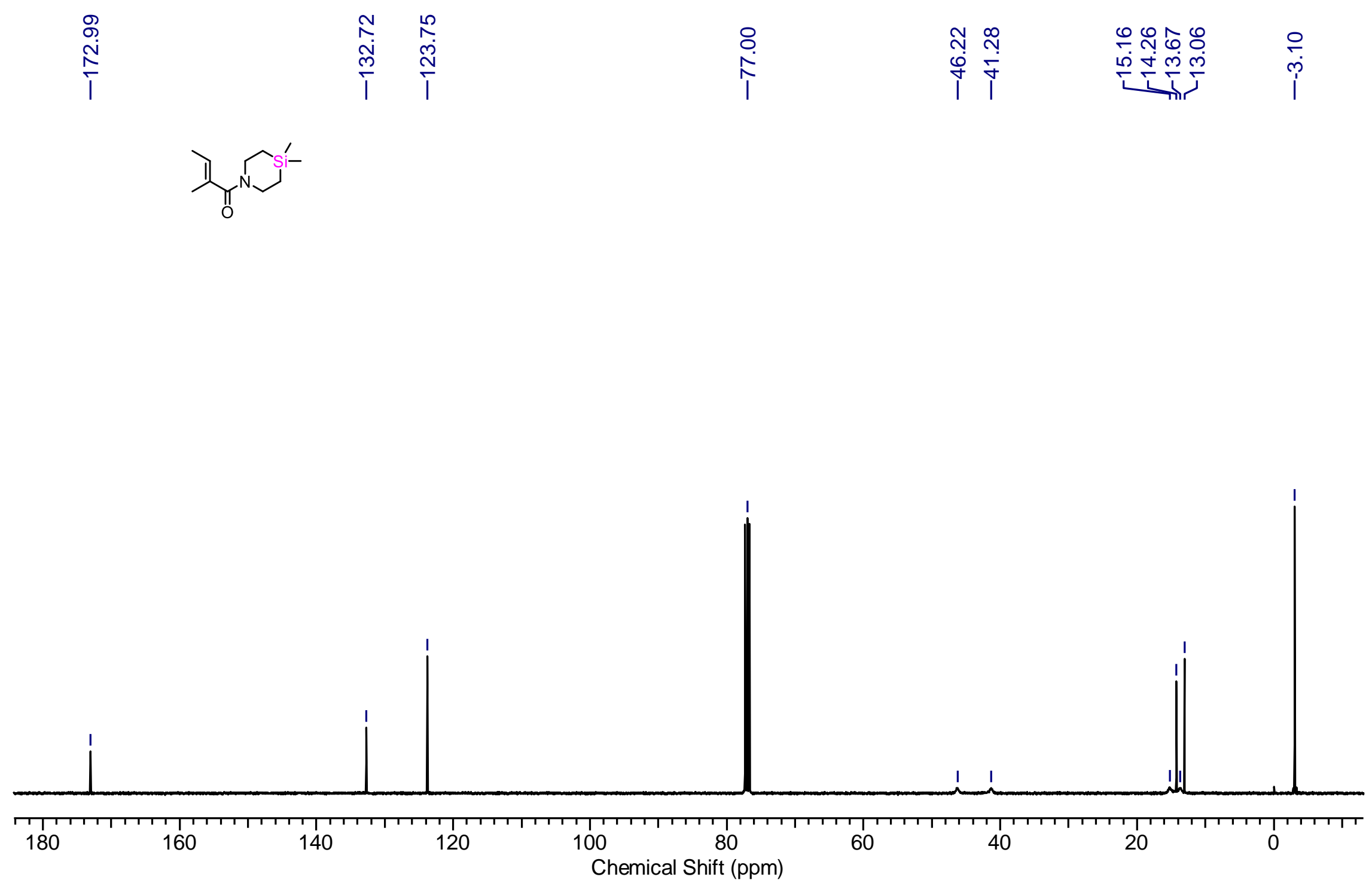


\section{Figure S37: ${ }^{1} \mathrm{H}$ NMR of 20 in $\mathrm{CDCl}_{3}(400 \mathrm{MHz})$}

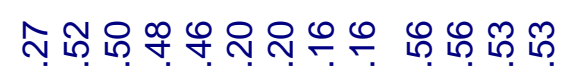

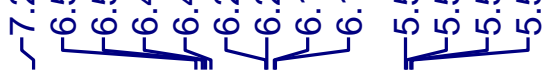

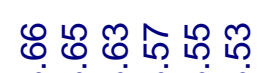

लू लिभुल
ำㅉํำ

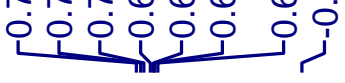

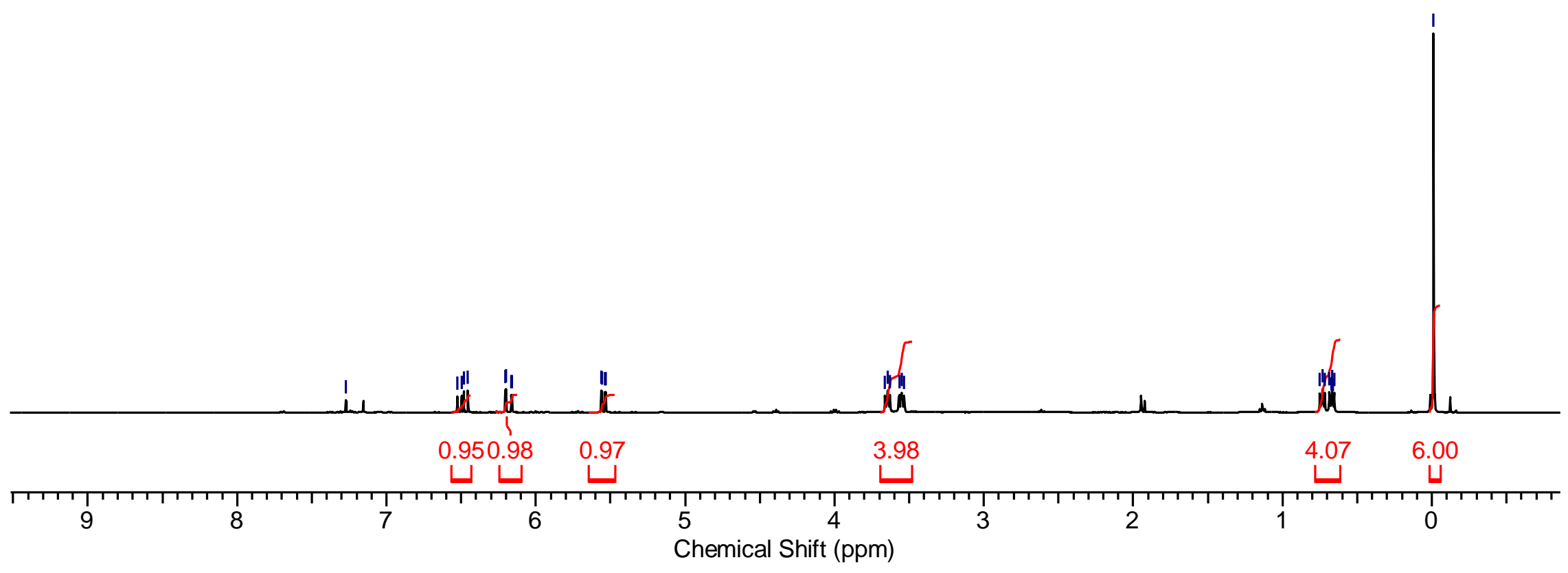




\section{Figure S38: ${ }^{13} \mathrm{C}$ NMR of 20 in $\mathrm{CDCl}_{3}(100 \mathrm{MHz})$}
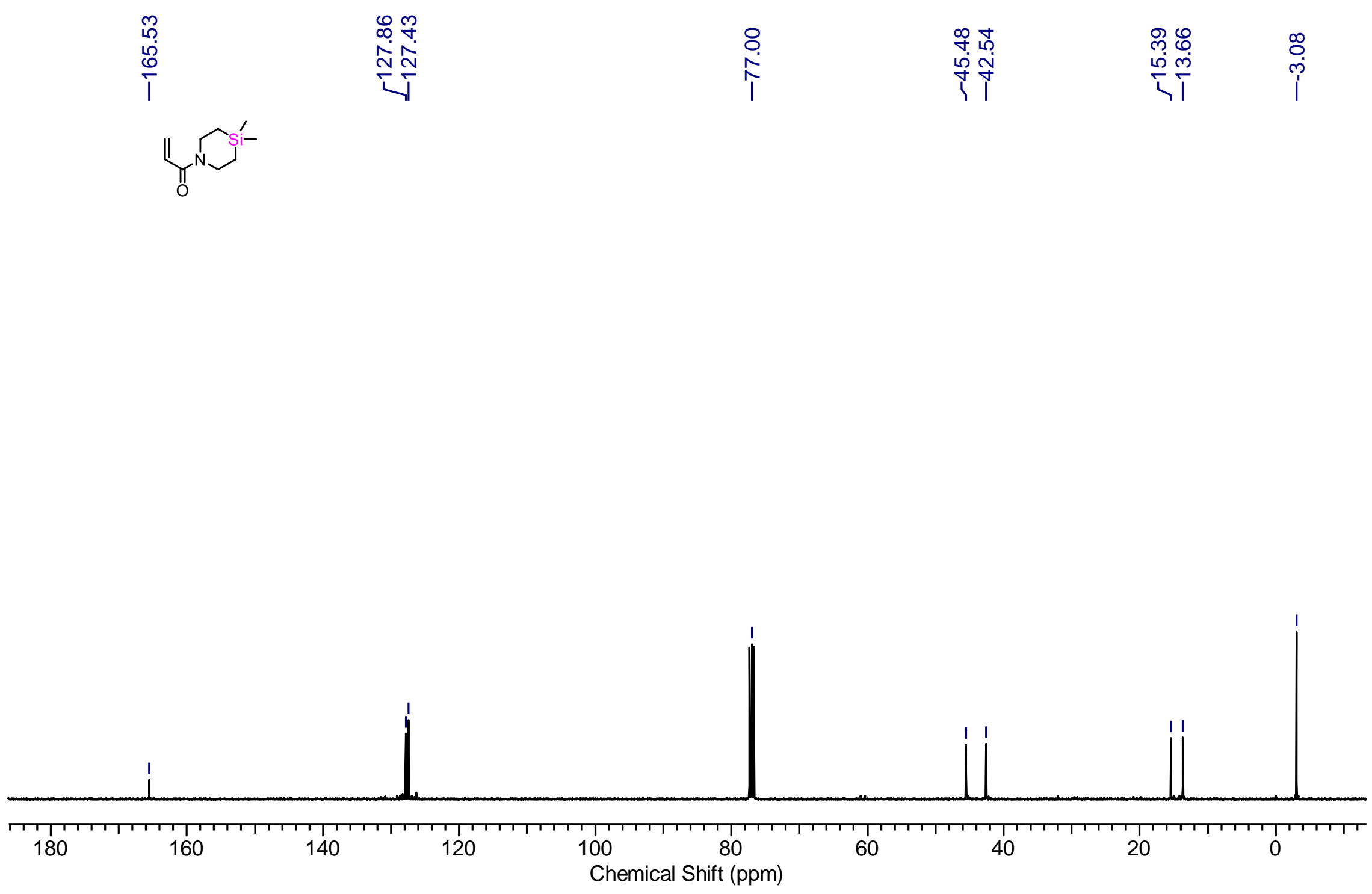


\section{Figure S39: ${ }^{1} \mathrm{H}$ NMR of 21 in $\mathrm{CDCl}_{3}(400 \mathrm{MHz})$}

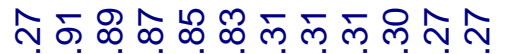

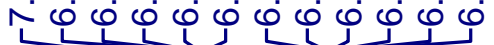

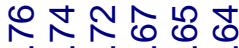

חூ œ نTI
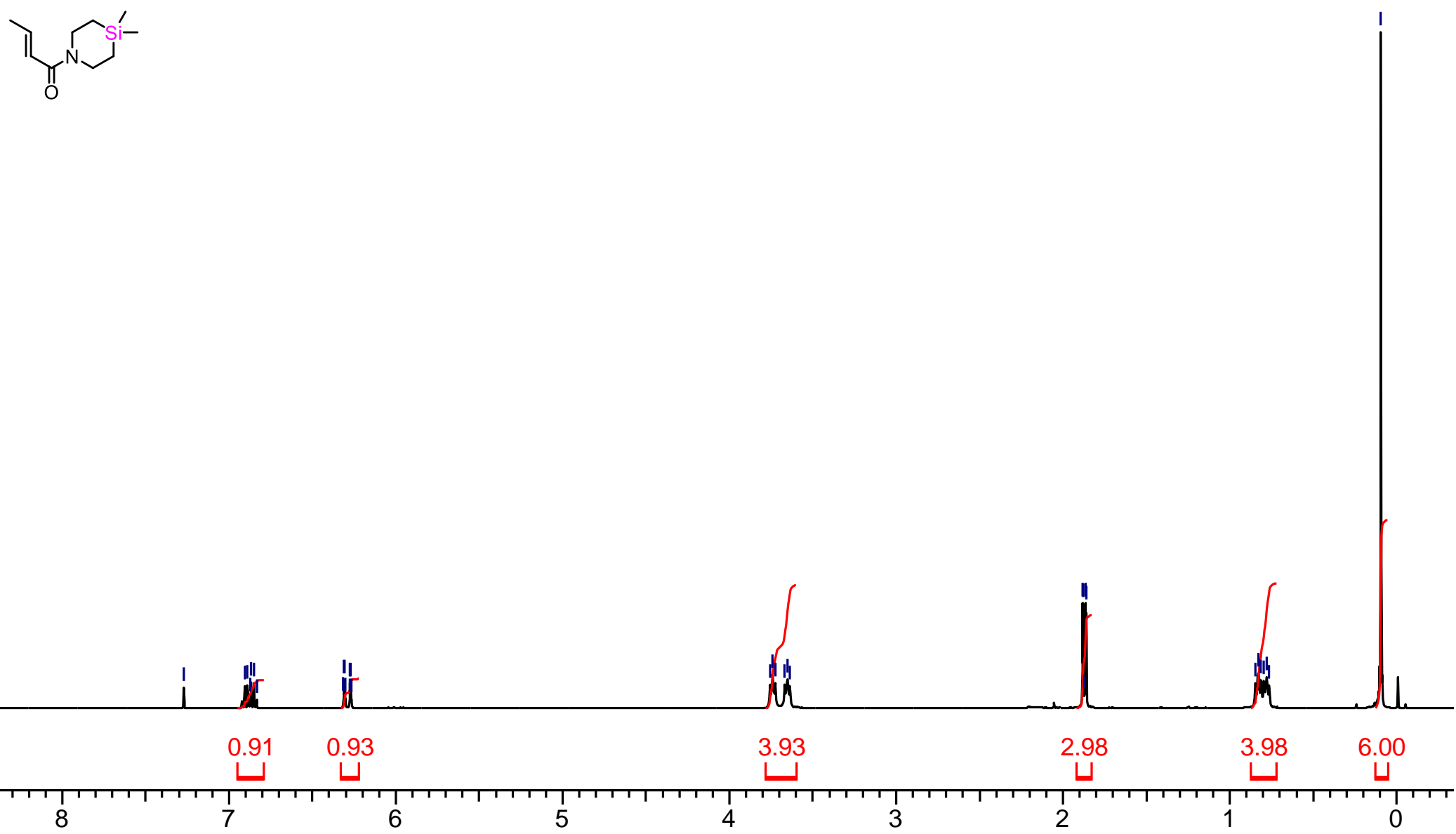


\section{Figure S41: ${ }^{1} \mathrm{H}$ NMR of 22 in $\mathrm{CDCl}_{3}(400 \mathrm{MHz})$}

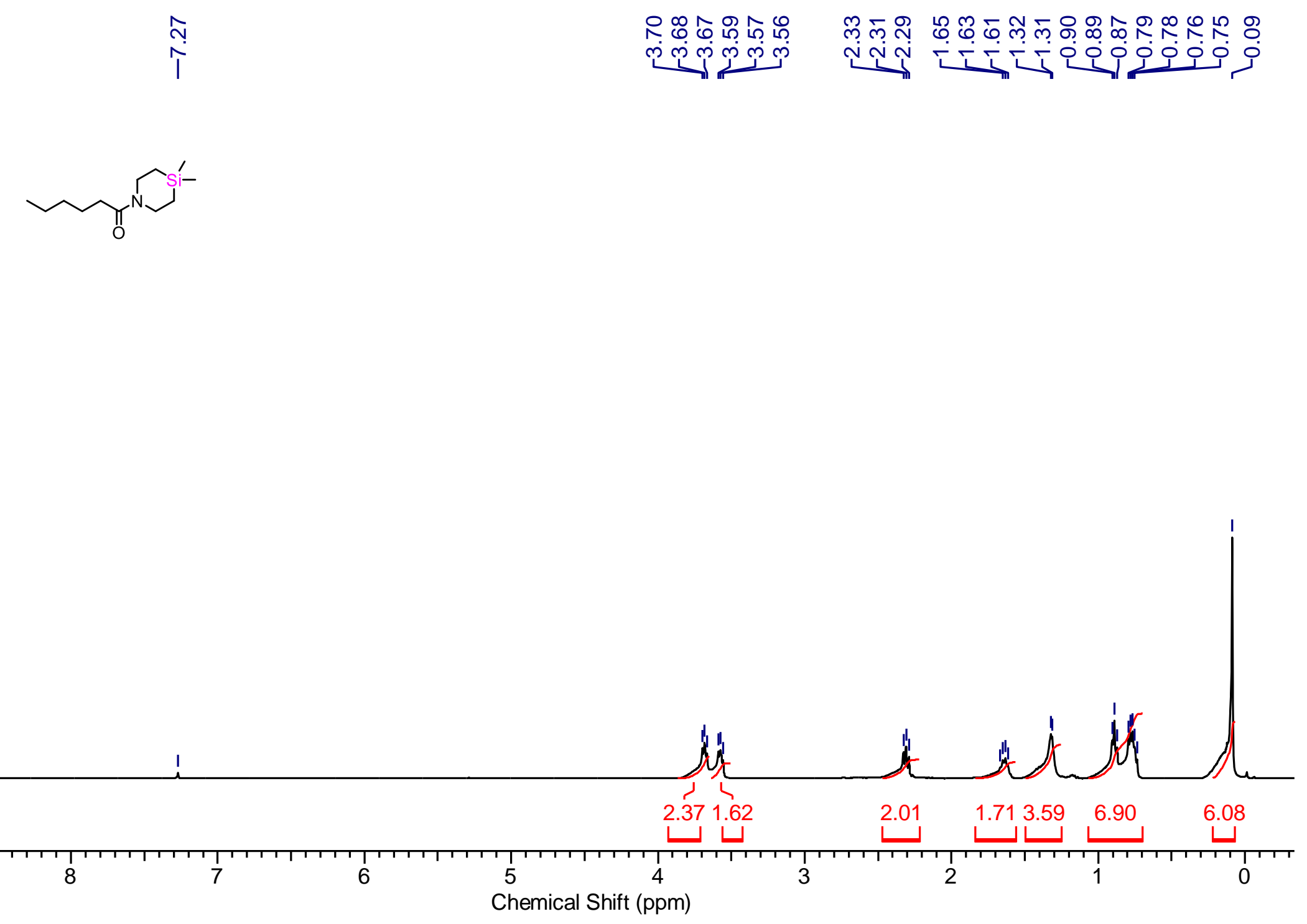




\section{Figure S42: ${ }^{13} \mathrm{C}$ NMR of 22 in $\mathrm{CDCl}_{3}(100 \mathrm{MHz})$}
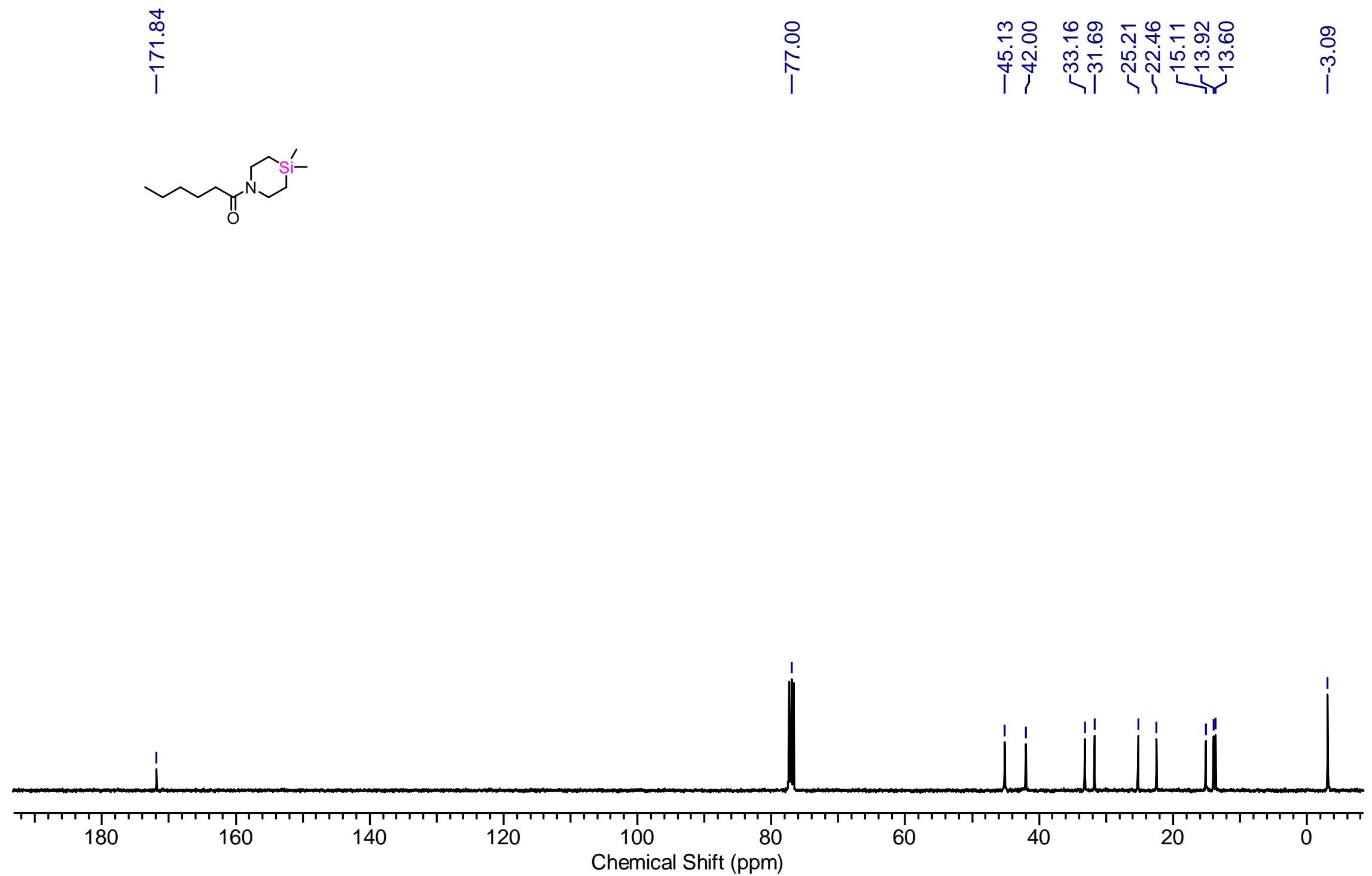


\section{Figure S43: ${ }^{1} \mathrm{H}$ NMR of 23 in $\mathrm{CDCl}_{3}(400 \mathrm{MHz})$}

în
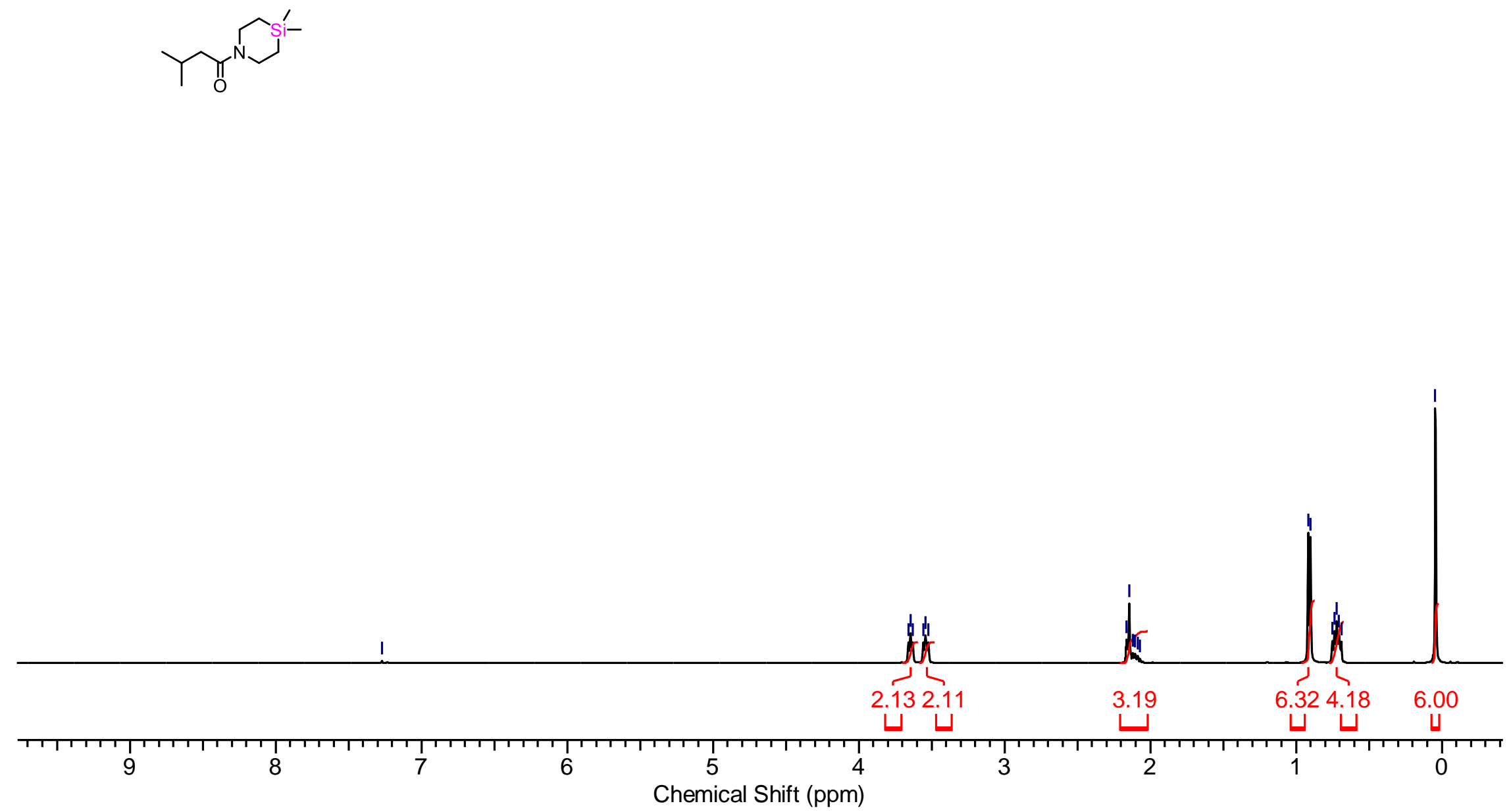


\section{Figure S44: ${ }^{13} \mathrm{C}$ NMR of 23 in $\mathrm{CDCl}_{3}(100 \mathrm{MHz})$}
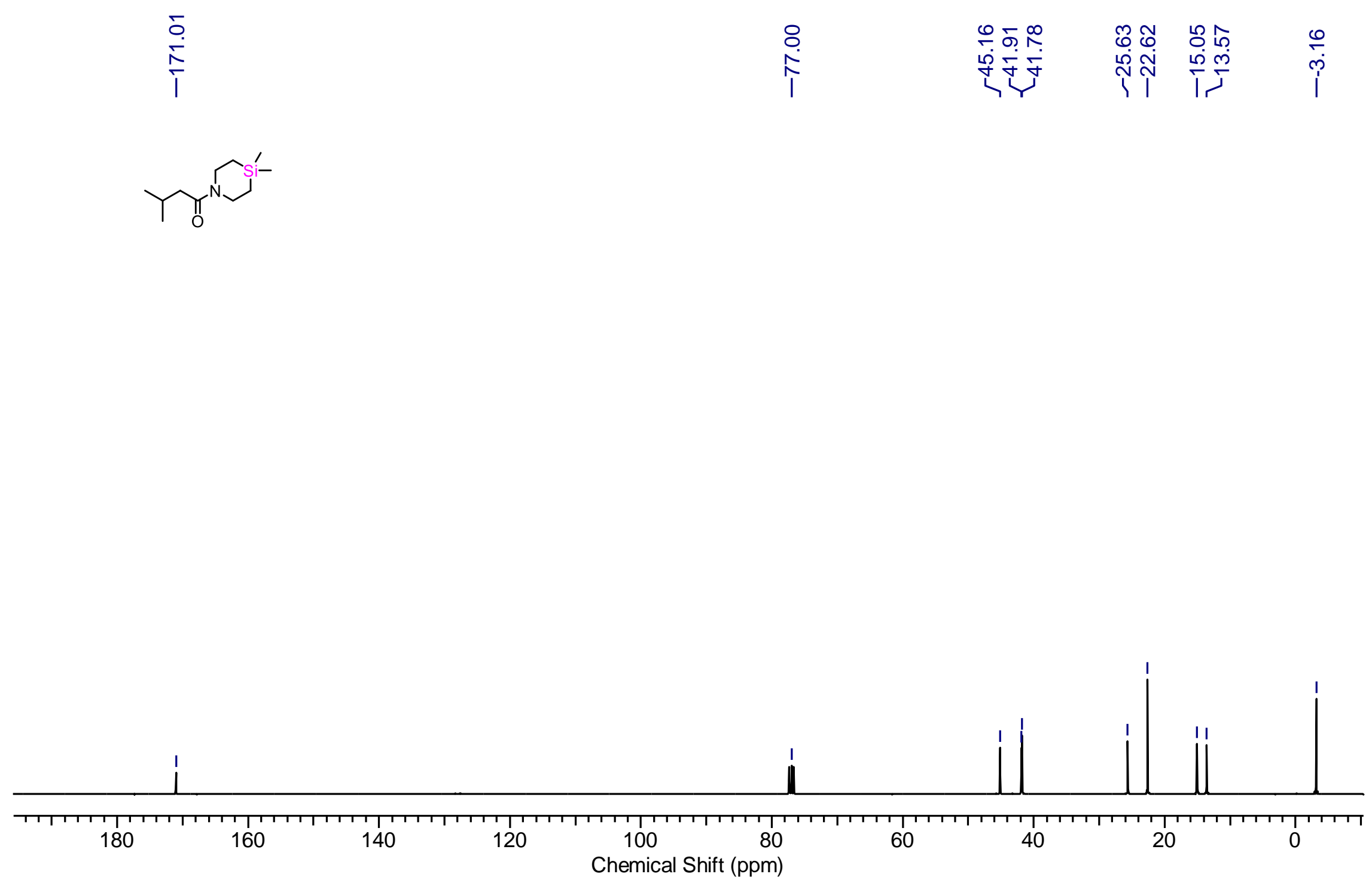


\section{Figure S45: ${ }^{1} \mathrm{H}$ NMR of 24 in $\mathrm{CDCl}_{3}(400 \mathrm{MHz})$}
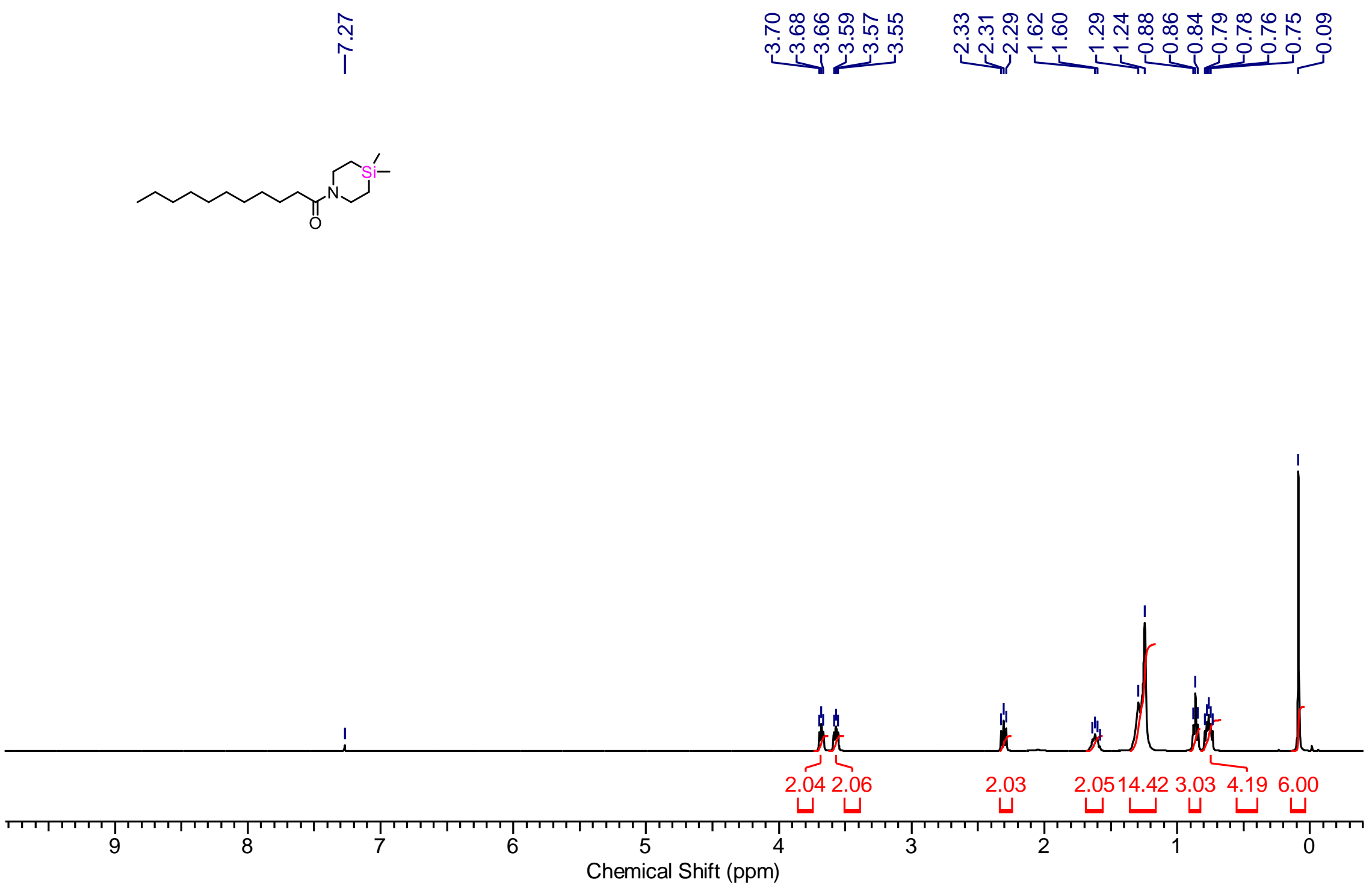


\section{Figure S46: ${ }^{13} \mathrm{C}$ NMR of 24 in $\mathrm{CDCl}_{3}(100 \mathrm{MHz})$}
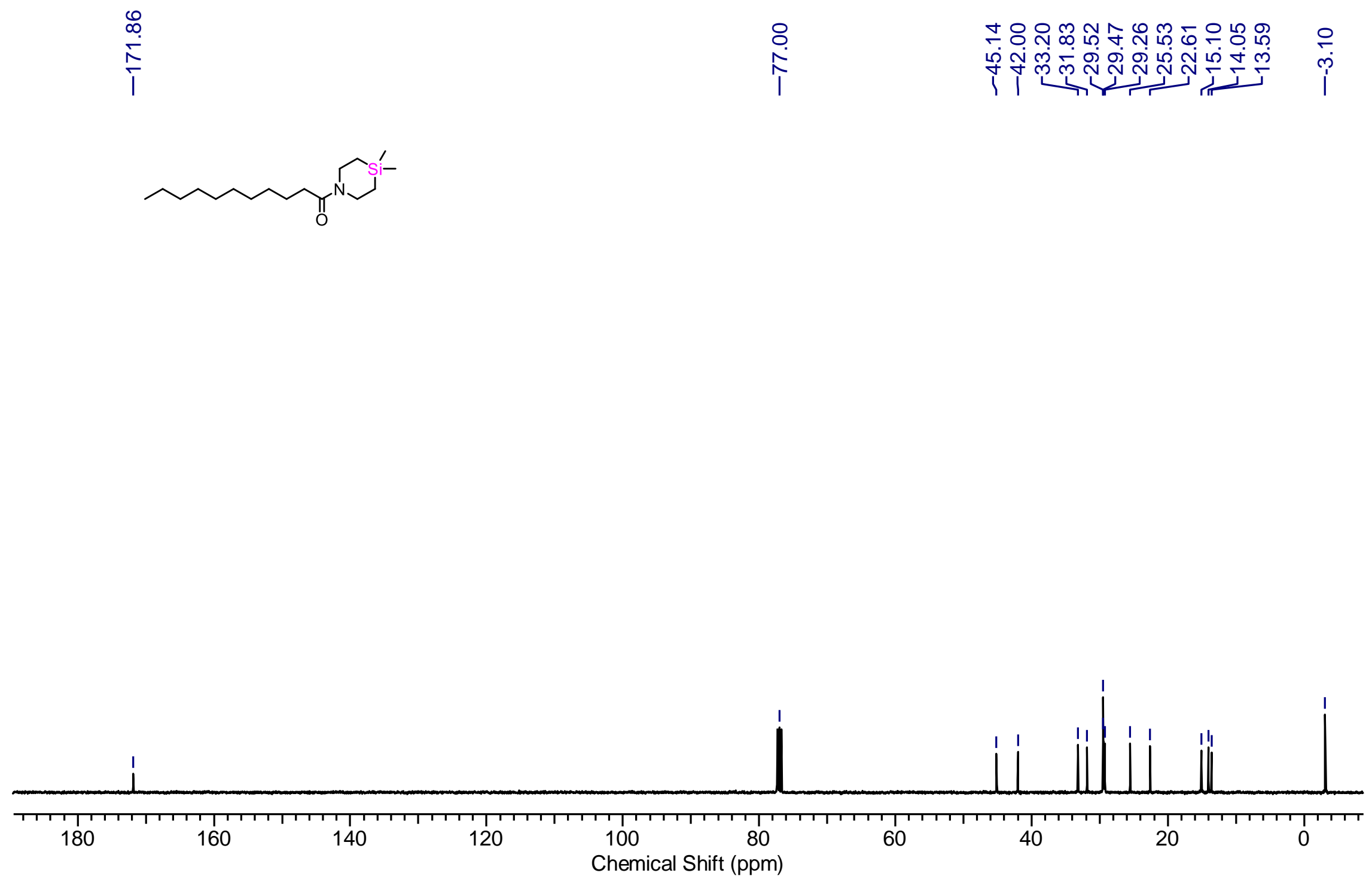


\section{Figure S47: ${ }^{1} \mathrm{H}$ NMR of 25 in $\mathrm{CDCl}_{3}(400 \mathrm{MHz})$}
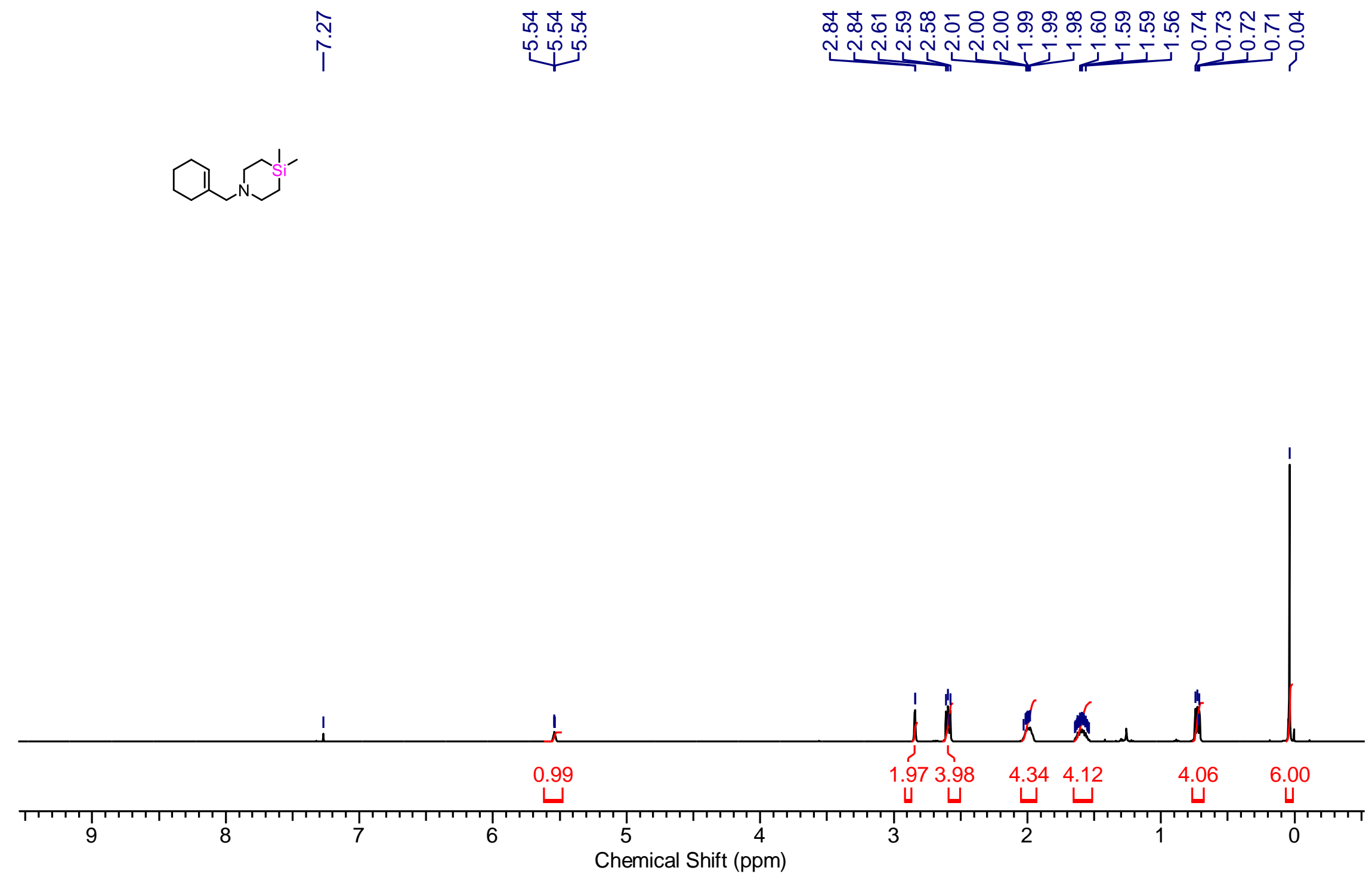


\section{Figure S48: ${ }^{13} \mathrm{C}$ NMR of 25 in $\mathrm{CDCl}_{3}(100 \mathrm{MHz})$}

\begin{tabular}{|c|c|c|c|c|}
\hline 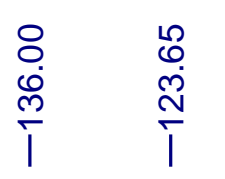 & $\begin{array}{l}8 \\
\stackrel{i}{i} \\
\text { in }\end{array}$ & $\begin{array}{l}\hat{f} \\
\stackrel{\leftrightarrow}{0} \\
\stackrel{1}{1}\end{array}$ & $\begin{array}{l}\bar{m} \\
\stackrel{p}{p} \\
\hat{p}\end{array}$ & 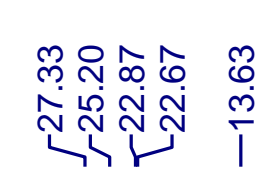 \\
\hline
\end{tabular}
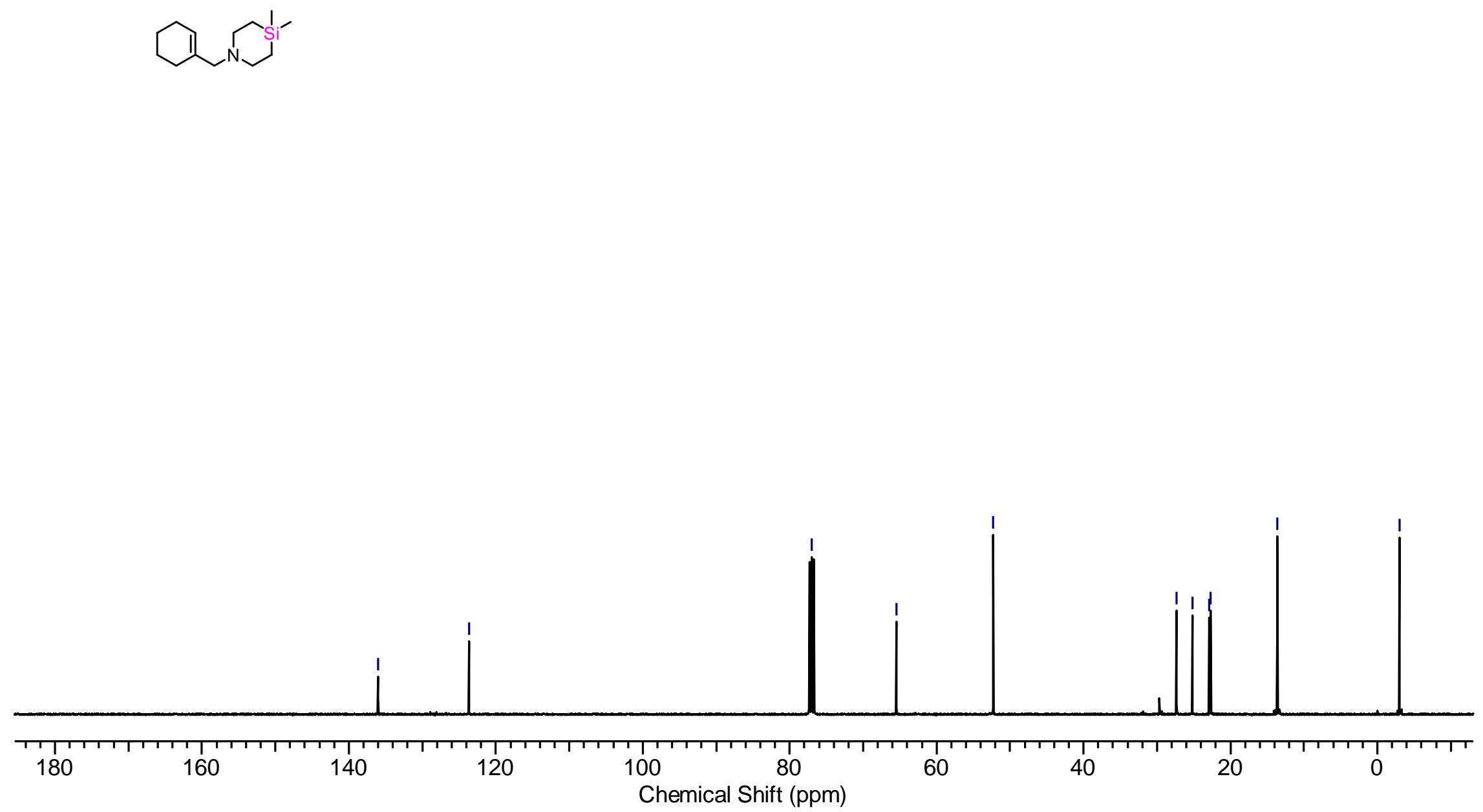


\section{Figure S49: ${ }^{1} \mathrm{H}$ NMR of 26 in $\mathrm{CDCl}_{3}(400 \mathrm{MHz})$}

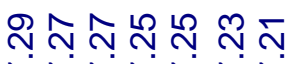

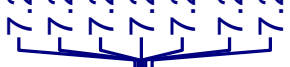

نَّ

사장ㅇㅇㅇㅠ

iipi i
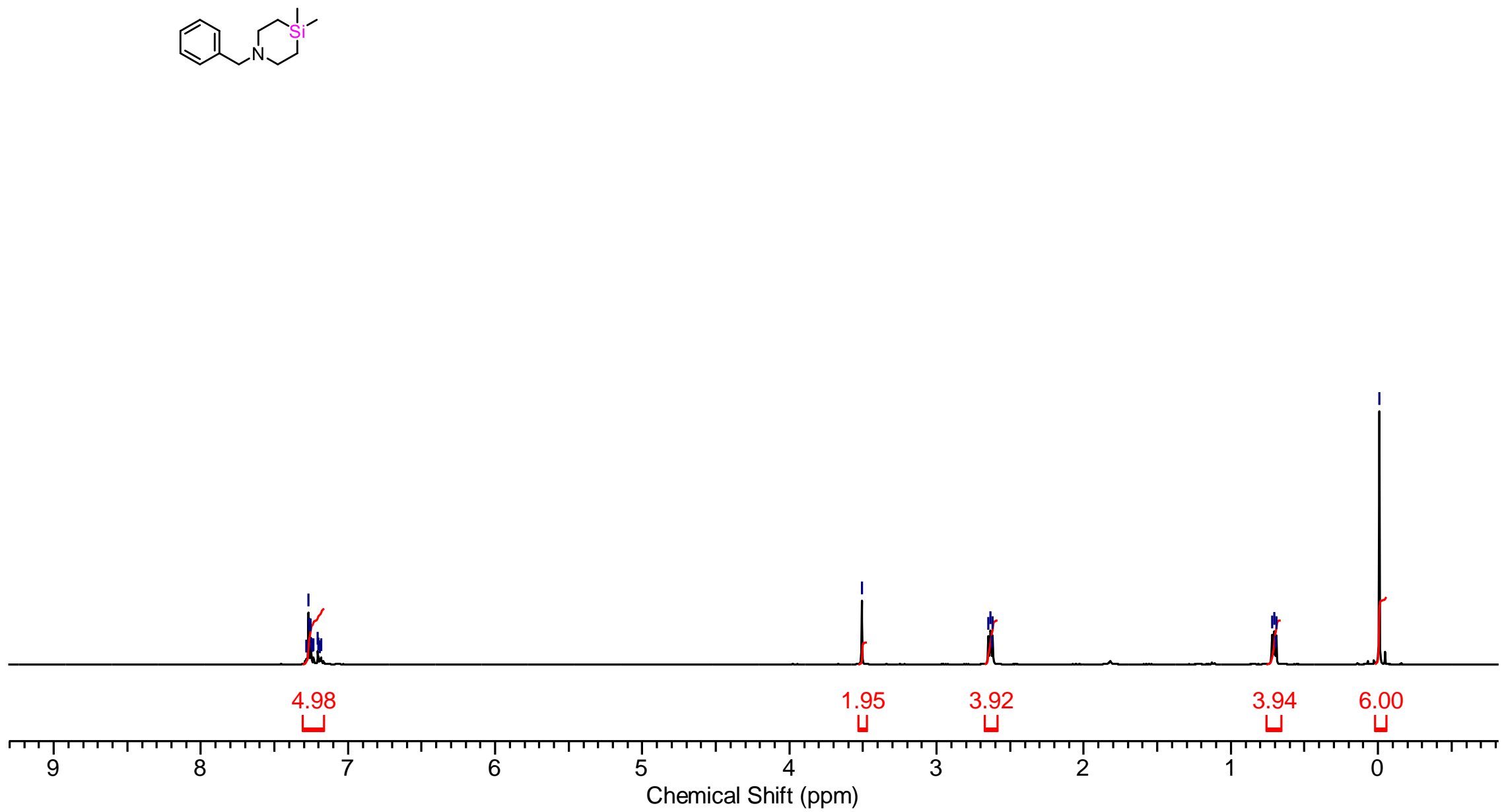


\section{Figure S50: ${ }^{13} \mathrm{C}$ NMR of 26 in $\mathrm{CDCl}_{3}(100 \mathrm{MHz})$}

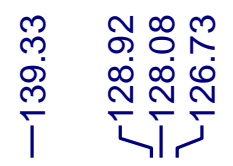

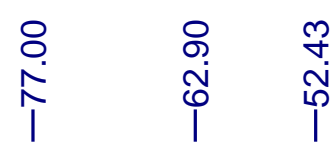
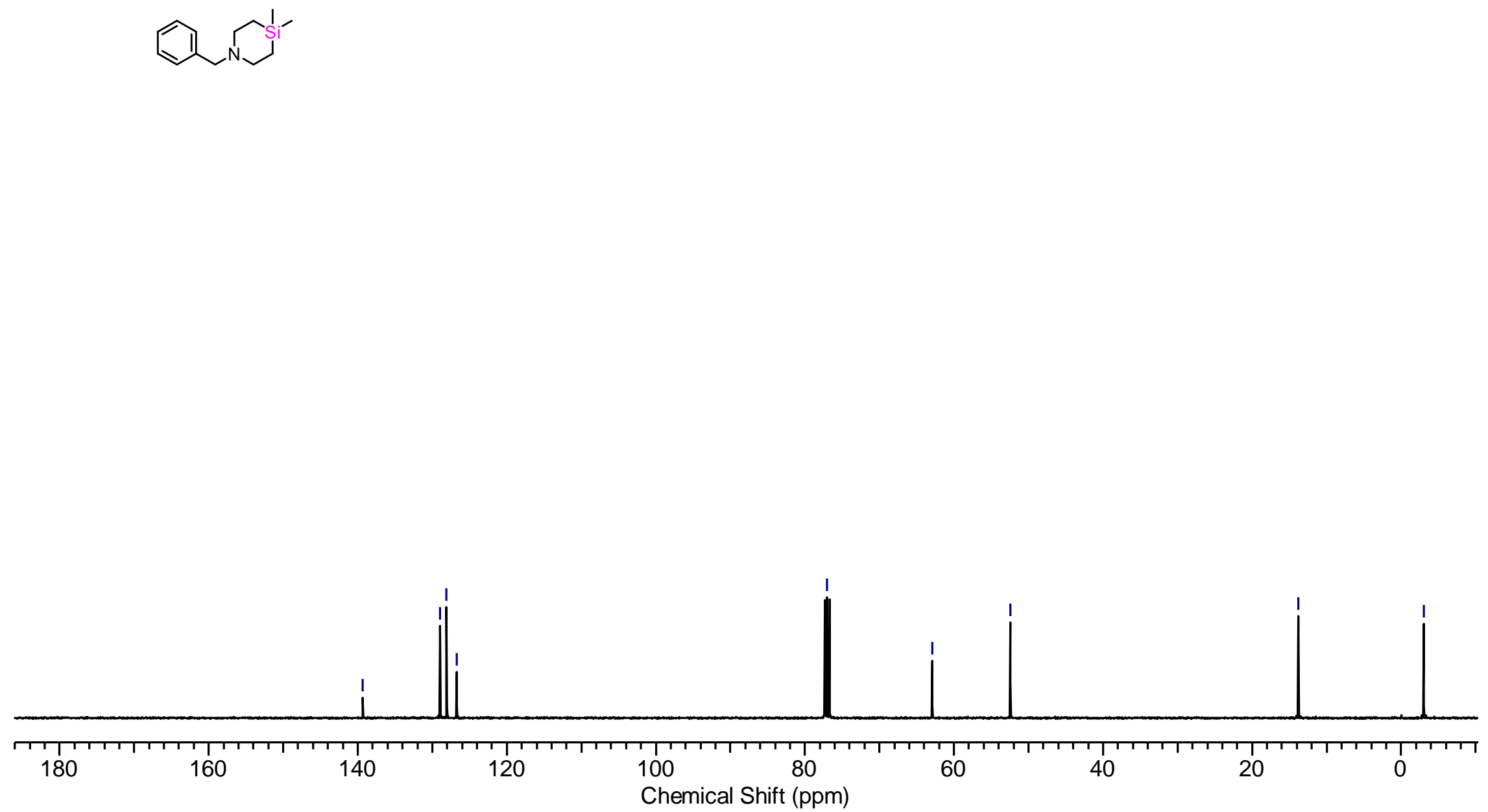


\section{Figure S51: ${ }^{1} \mathrm{H}$ NMR of 29 in $\mathrm{CDCl}_{3}(400 \mathrm{MHz})$}
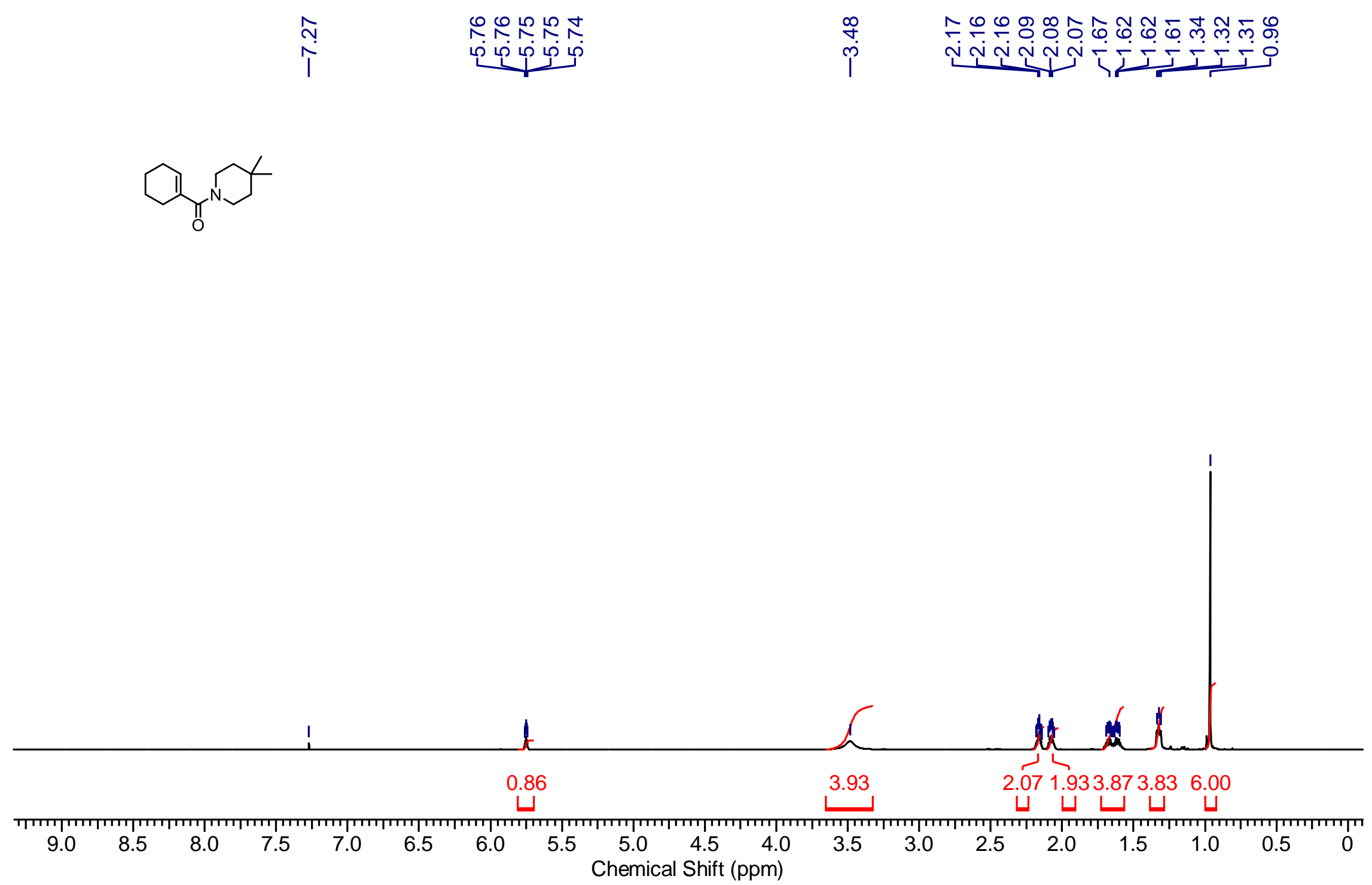


\section{Figure S52: ${ }^{13} \mathrm{C}$ NMR of 29 in $\mathrm{CDCl}_{3}(100 \mathrm{MHz})$}

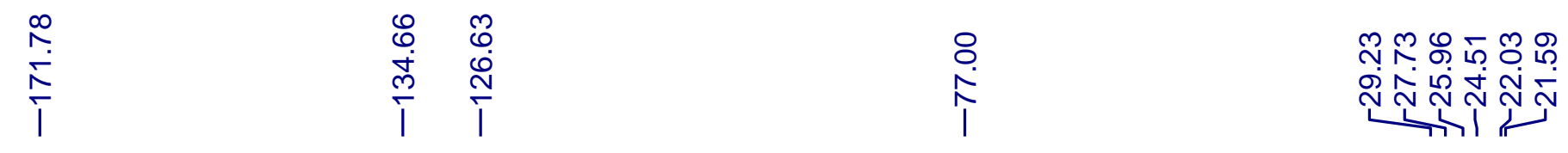
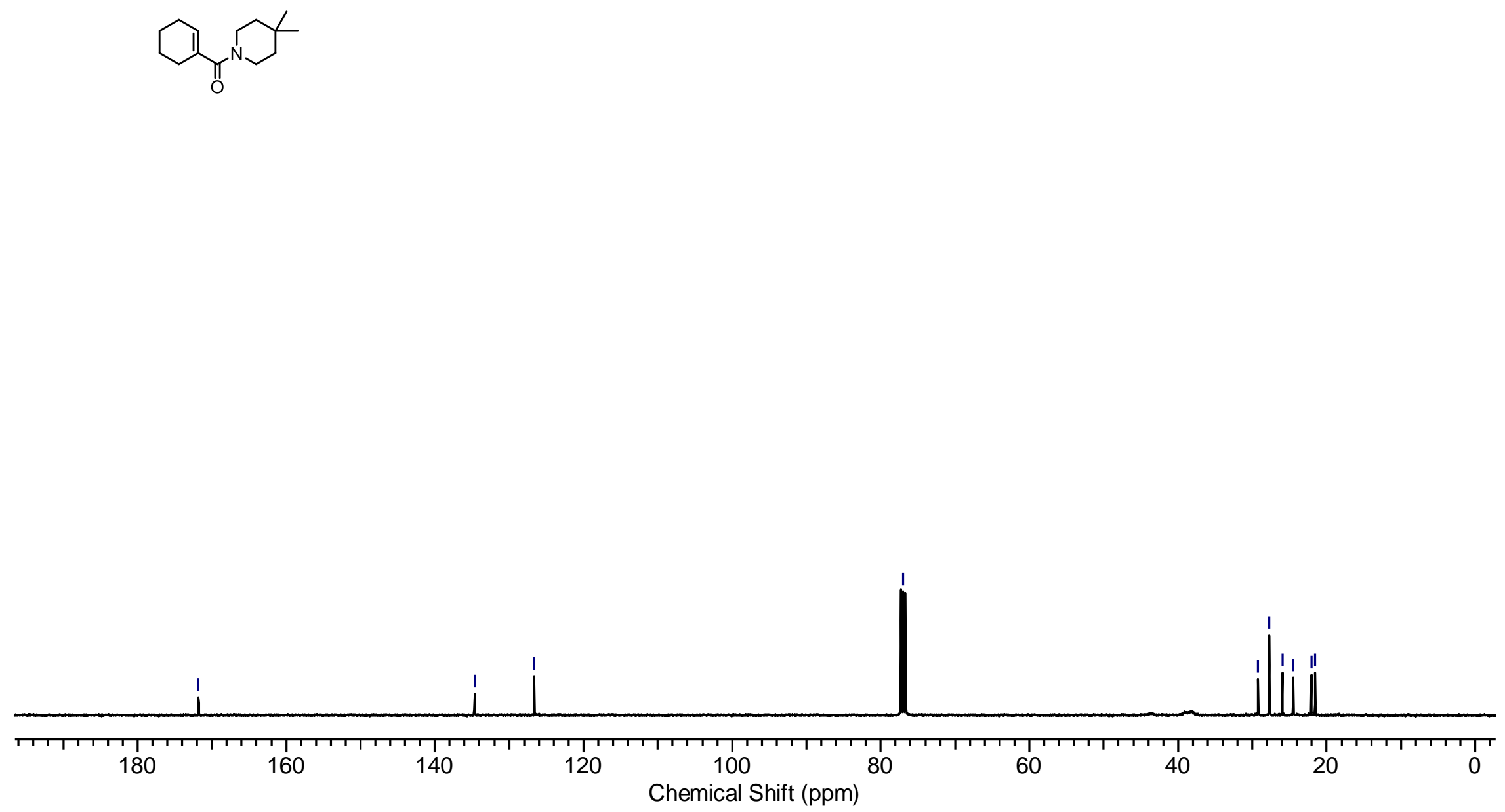